NBER WORKING PAPER SERIES

\title{
WHEN AND HOW TO USE PUBLIC-PRIVATE PARTNERSHIPS IN INFRASTRUCTURE: LESSONS FROM THE INTERNATIONAL EXPERIENCE
}

\author{
Eduardo Engel \\ Ronald D. Fischer \\ Alexander Galetovic \\ Working Paper 26766 \\ http://www.nber.org/papers/w26766 \\ NATIONAL BUREAU OF ECONOMIC RESEARCH \\ 1050 Massachusetts Avenue \\ Cambridge, MA 02138 \\ February 2020
}

We are thankful to Ed Glaeser, Keith Hennessey, James Poterba and conference participants for their comments and suggestions. We thank Nicolás Campos for outstanding research assistance. Fischer gratefully acknowledges the financial support from the Complex Engineering Systems Institute (CONICYT - PIA - FB0816) and the Instituto Milenio MIPP IS130002. The views expressed herein are those of the authors and do not necessarily reflect the views of the National Bureau of Economic Research.

NBER working papers are circulated for discussion and comment purposes. They have not been peer-reviewed or been subject to the review by the NBER Board of Directors that accompanies official NBER publications.

(C) 2020 by Eduardo Engel, Ronald D. Fischer, and Alexander Galetovic. All rights reserved. Short sections of text, not to exceed two paragraphs, may be quoted without explicit permission provided that full credit, including $(\odot$ notice, is given to the source. 
When and How to Use Public-Private Partnerships in Infrastructure: Lessons From the International Experience

Eduardo Engel, Ronald D. Fischer, and Alexander Galetovic

NBER Working Paper No. 26766

February 2020

JEL No. H11,H42,H83

\begin{abstract}
Public-private partnerships (PPPs) have emerged as a new organizational form to provide public infrastructure over the last 30 years. Governments find them attractive because PPPs can be used to avoid fiscal check-and-balances and increase spending. At the same time, PPPs can lead to important efficiency gains, especially for transportation infrastructure. These gains include better maintenance, reduced bureaucratic costs, and filtering white elephants. For these gains to materialize, it is necessary to deal with the governance of PPPs, which is more demanding than for the public provision of infrastructure. The governance can be improved by the use of contracts with appropriate risk allocation and by avoiding opportunistic renegotiations, which have been pervasive. The good news is that, based on the experience with PPPs over the last three decades, we have learnt how to address these challenges.
\end{abstract}

Eduardo Engel

University of Chile

Department of Economics

Diagonal Paraguay 257

Santiago

CHILE

emraengel@gmail.com

Ronald D. Fischer

Centro de Economia Aplicada (CEA)

Departamento de Ingenieria Industrial

Universidad de Chile

Republica 701 Santiago CHILE

rfischer@dii.uchile.cl

\author{
Alexander Galetovic \\ Adolfo Ibáñez University \\ Diagonal Las Torres 2640 \\ Peñalolen \\ Santiago \\ CHILE \\ alexander@galetovic.cl
}




\section{Contents}

1 Introduction $\quad 3$

$2 \quad$ PPPs around the world $\quad 7$

2.1 World infrastructure and $\mathrm{PPP} \ldots \ldots \ldots \ldots \ldots \ldots$

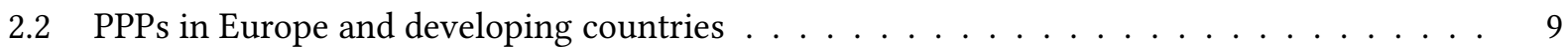

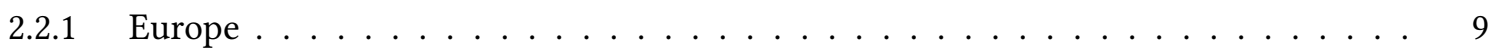

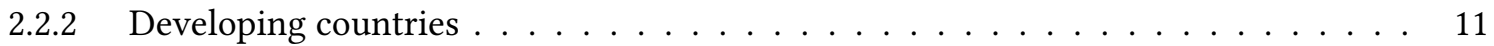

3 Why governments use PPPs: Fiscal accounting 12

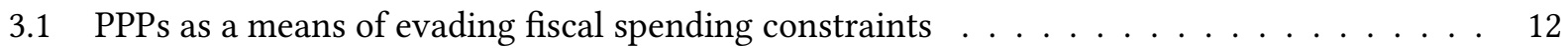

3.2 Distorted Policy choices . . . . . . . . . . . . . . . . . . . . . . . 15

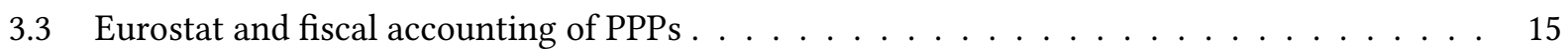

4 Economic arguments for PPPs: Incentives, risk and efficiency $\quad 15$

4.1 Efficiency . . . . . . . . . . . . . . . . . . . . . . . 15

4.2 Incentives and risk allocation $\ldots \ldots \ldots \ldots \ldots \ldots$

5 Governance and renegotiations $\quad 20$

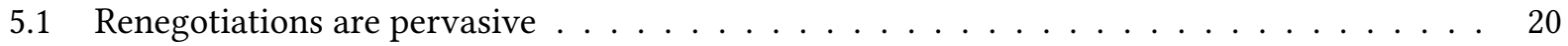

5.2 The origin and consequence of renegotiations $\ldots \ldots \ldots \ldots \ldots \ldots \ldots \ldots$

5.3 Governance and remedies . . . . . . . . . . . . . . . . . . . . . . . . 23

6 PVR contracts $\quad 24$

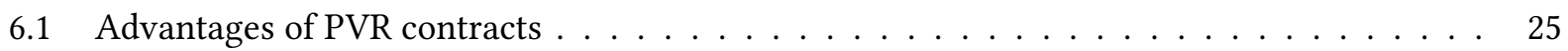

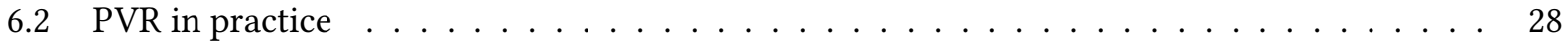

6.3 Financing and renegotiations: theory and evidence $\ldots \ldots \ldots \ldots$

7 Conclusion $\quad 31$ 


\section{Introduction}

Public-private partnerships, also known as PPPs, P3s and concessions, emerged in recent decades as a new organizational form to provide public infrastructure. ${ }^{2}$ Even though public provision continues to be the dominant procurement option, investment in transport PPPs over the last 25 years has been considerable, adding $€ 203$ billion in Europe and $\$ 535$ billion in developing countries. ${ }^{3}$ In some countries, investment via PPPs in other types of infrastructure, such as hospitals and schools has also been significant. By comparison, PPP investments in the US have been relatively small.

PPPs are funded by a combination of user fees and government transfers. For example, when demand is sufficiently high, a toll road can be funded entirely with tolls, while government transfers are usually the main funding source for schools and hospitals. In general, under a PPP the firm finances, builds, operates and maintains the project. The contract term is long, usually of 20 to 40 years for a highway, and the facility reverts to the government when the concession ends. At that point the government can initiate a new concession, involving additional investments and revamping of the existing infrastructure, or manage the infrastructure itself.

\section{Why do governments choose PPPs? Political Economy reasons}

The main reason why governments have chosen PPPs is that this organizational form allows them to spend more on infrastructure, for two related reasons. First and in contrast to public provision, most of the investment via PPPs is not included as public debt, nor does it contribute to the fiscal deficit, at least in the short run. This is attractive for governments constrained by fiscal rules or international agreements, like the Maastricht Treaty, that limit their levels of debt and deficits. ${ }^{4}$ The second reason why PPPs allow governments to spend more is that these investments are usually not subject to Congressional oversight and other budgetary controls. Therefore, they allow incumbents more discretion.

Nevertheless, the fiscal impact of a project in present value is the same, independently of the type of procurement (PPP or traditional provision). For example, by choosing a PPP over traditional provision to provide a toll road, government saves by not having to pay for the upfront investment. However, these savings are equal, in present value, to the toll revenues government forgoes during the duration of the concession. This equivalence result also debunks the often used argument that PPPs free up government resources, an argument that ignores the fiscal impact of PPPs after the project is built. ${ }^{5}$

It follows that investments in infrastructure via PPPs should be recorded in fiscal accounts in the same way as public investments (see Engel et al., 2013, for a formal treatment) ${ }^{6}$ The preferential treatment of

\footnotetext{
${ }^{2}$ See Grimsey and Lewis (2004) and OECD (2008) for general introductions to PPPs.

${ }^{3}$ Sources: EIB (1990-2018) and PPIAF (1990-2018).

4 "Cynics suspect that the government remains keen on PFI not because of the efficiency it allegedly offers, but because it allows ministers to perform a useful accounting trick.” The Economist, July 2nd, 2009. PFI is the acronym for the UK's PPP program.

5"The boom [in PPPs] is good news for governments with overstretched public finances: many local and national authorities have found themselves sitting on toll roads, ports, and airports that they can sell for billions of dollars to fund other public services." Financial Times, July 5th, 2007.

${ }^{6}$ This recommendation does not rule out having a dollar of investment in public infrastructure count less than a dollar of other types of government expenditure as argued by Blanchard and Giavazzi (2004). It should be understood to mean that such a differential treatment should apply both to public provision and to PPPs.
} 
PPPs has led to higher deficits and to projects being provided as PPPs when public provision was more efficient. ${ }^{7}$

Sometimes governments choose PPPs for ideological reasons: PPPs are a second best option to replace an incompetent public sector with an efficient private sector when privatization is not possible. This argument is incorrect since first, it omits that the private sector is involved in public provision of infrastructure: as designers, builders and often as operators and maintainers of public infrastructure. Second, because providing efficient infrastructure services under a PPP requires stronger government capabilities than under public provision. The financial aspects of PPPs are more complex and there is more scope for opportunistic behavior, because the contractual relationship between the firm and the government is long-lasting under a PPP. These issues are at the core of the governance challenges for PPPs that we discuss below.

\section{Why governments should choose PPPs: Economic reasons}

An economic argument for PPPs is that governments should choose PPPs over public provision when they provide sufficient efficiency gains. Since private firms are involved in building infrastructure projects both under public provision and PPPs, efficiency gains do not arise from private participation per se, but from the different incentives under both organizational forms. These may be due to differences in risk allocation, contract design, financing, and political economy.

Seven efficiency claims are advanced to prefer PPPs over public provision: narrow focus and dedicated management, the advantages of bundling, fewer delays in construction, filtering white elephants, avoiding the cost of bureaucracies, the disciplining effects of private financing and better (and often cheaper) maintenance. We review these arguments next.

Narrow focus and dedicated management: A PPP is a private entity whose contracting relations with employees, other firms and financiers are governed by private law. This improves incentives, because during the term of the PPP, the private firm can manage the infrastructure as a private entity, bound by the contract with the Public Authority. Moreover, by creating a firm (called Special Purpose Vehicle or SPV) to build and manage the infrastructure project, the scope of the firm is clearly defined and bounded, and the project gets a dedicated management team, which answers to the firm's board.

Bundling: PPPs provide incentives to make non-contractible investments during construction that may reduce maintenance and operations costs over the lifecycle of the concession (Grout, 2003; Hart, 2003). No such incentives are present under public provision since different firms are in charge of construction and operations. This 'bundling argument' in favor of PPPs requires that quality of service be contractible, for otherwise the concessionaire may lower costs by degrading the quality of service. Singh (2018) provides evidence that PPPs encourage the life-cycle approach toward maintenance.

Fewer construction delays: Incentives to avoid delays are large if a PPP can only begin charging user fees, or receiving government transfers, once the project is operational.

\footnotetext{
7 "Some have argued that the structuring of Network Rail and the pursuit of PFI deals were influenced by the fiscal rules in place at the time. It is not for us to comment on the motivation behind these decisions, but it is possible to see why people might believe that their statistical treatment may have played a part." Fiscal risks report. UK Office of Budget Responsibility. 2017.
} 
The two efficiency arguments in favor of PPPs that follow apply when the project is funded mainly with user fees.

Filtering white elephants: In the absence of government transfers, PPPs will filter white elephants, since no firm will be interested in a project where user fees cannot pay for capital and operational expenditures. This insight goes back to Adam Smith. ${ }^{8}$

Avoiding the cost of bureaucracies: PPPs allow users to pay the firm building and operating the infrastructure asset directly, avoiding the efficiency costs associated with spending money via government bureaucracies (see Engel et al., 2013, for a formal model). These efficiency costs are caused by two related factors: the justifiable rigidities in public spending, and to the costs of corruption those rigidities are meant to reduce.

Advantages of private financing: PPPs developed hand-in-hand with project finance, a technique based on lending against the cash flow of a project that is legally and economically self-contained. Banks are usually the main financiers during construction, helping to mitigate moral hazard by exercising tight control over changes in the project's design and disbursing funds only gradually as project stages are completed. The oversight under public provision is weaker due to increased moral hazard because of looser incentives.

Better and less expensive maintenance: In many countries there is a bias in spending in favor of new infrastructure and against the maintenance of existing infrastructure, because new infrastructure is more visible and can be used to increase an incumbent's reelection probability. ${ }^{9}$ Also, the annual logic of public budgets makes it difficult to set aside resources for future maintenance at the time the project is built.

The cost of poor maintenance under public provision can be very high. Not only is average quality of service much lower than if maintenance were continuous but the overall cost of maintenance is much higher. For example, in the case of highways, the cost of intermittent maintenance, that often involves costly rehabilitations, has been estimated to be between 1.5 and 3 times the cost of continuous maintenance, which is the most efficient approach. ${ }^{10}$ Recent studies (see Leslie, 2018, and references therein) suggest that PPPs may involve important efficiency gains from better maintenance for other types of infrastructure services, prominent among them hospitals.

PPPs solve the maintenance problem of public provision if the quality of the services provided by the infrastructure asset is contractible. It then suffices to include service quality specifications in the contract and to enforce them on a regular basis during the lifetime of the contract. In the case of highways, which account for the largest fraction of investment in PPPs, the efficiency gains associated with better and cheaper maintenance are likely to be large. On the cost side, these savings are somewhere between 10 and 16 percent of initial investments. ${ }^{11}$

\footnotetext{
8"When high roads are made and supported by the commerce that is carried on by means of them, they can be made only where that commerce requires them. [...] A magnificent road cannot be made merely because it happens to lead to the country villa of the intendant of the province [...]" Adam Smith, Wealth of Nations, 1776.

${ }^{9}$ Rioja (2003) estimates, based on social welfare criteria, that one third of expenditures on new infrastructure should be allocated to maintaining existing projects.

${ }^{10}$ See TRiP (2013) for the lower bound, which applies to the US, and Engel et al. (2014) for the upper bound, which is obtained for developing countries. The difference grows with the extent to which the road is allowed to deteriorate before it is rehabilitated.

${ }^{11} \mathrm{We}$ arrive at this range as follows: Annual maintenance costs of a typical highway are typically between 2 and 3 percent of
} 


\section{Governance and renegotiations}

Providing infrastructure services under a PPP requires higher government capabilities than under public provision. Financing is more complex and there is more scope for opportunistic behavior, because the contractual relationship between the firm and the government lasts much longer under a PPP. For this reason, sufficient state capabilities are needed for a successful PPP program.

Many PPP projects have been bailed out by governments, which can turn the public against PPPs. For example, public support for the Public Finance Initiative (or PFI) of the UK, never recovered after the bailout of the London Underground PPP in 2008, which cost taxpayers somewhere between $£ 170$ million and $£ 410$ million (NAO, 2018). This may explain, in part, why PPP investments in the last decade are a small fraction of what they were at their peak in the early 2000s.

Bailouts are one extreme form of renegotiation, where government fully takes downside risk. More generally, contract renegotiations that modify the initial contract have been pervasive under PPPs. This means that many of the avowed efficiency advantages of PPPs are not realized. Even though incompleteness is to be expected in a complex contract that lasts several decades, the evidence suggests that renegotiations are often due to poor project and contract design, opportunistic behavior by concessionaires, the desire of incumbents to increase spending in infrastructure, and outright corruption.

When concessionaires expect to be bailed out if there is low demand for the project, PPPs do not filter white elephants. Similarly, incentives for careful project and contract design are weak when lack of diligence at the design stage can be corrected by altering the project during construction. Even more worrisome, when contract renegotiations become central to the PPP business model, firms that are good at renegotiating and lobbying have an advantage, as they can bid more aggressively when the project is tendered, in the expectation of recovering profitability when renegotiations take place.

In contrast to public provision, PPPs involve a long term relation between the concessionaire and government. A benefit for the current government is that it can ask for additional works to the initial project, and pay for it with an extension of the concession term or with payment obligations on future administrations. The additional spending does not go through the usual budgetary oversight process. The effect is to reduce the resources available to future governments. Moreover, the new works are likely to become more expensive because they are usually not tendered under competition.

Recent evidence from Latin America shows a connection between renegotiations and corruption. Campos et al. (2019) consider all projects undertaken by the Brazilian conglomerate Odebrecht in eight countries over a ten year period, and find that the average renegotiation, as a fraction of the initial investment, was 71 percent for projects where bribes were paid, compared with 6 percent for projects with no bribes. These percentages do not differ substantially between PPPs and public provision, suggesting that renegotiations are always problematic when providing public infrastructure.

Costly renegotiations can be reduced by making them less attractive for concessionaires and public authorities. For example, the contract can include the requirement that any significant addition to the project should be assigned in a competitive auction, where the owners of the SPV cannot participate. An-

the initial investment. Over a thirty year period, discounted at 5 percent, this adds up to between 32 and 48 percent. Using the $3: 1$ ratio of maintenance costs under continuous and intermittent maintenance then leads to the 10 to 16 percent range for savings. 
other helpful measure in reducing the incentives to renegotiate is the creation of independent, specialized entities that review and approve renegotiations to ensure that the SPV and its owners do not benefit from the increased value of the project.

Costly renegotiations can also be avoided by using contracts with better risk allocation. In the standard fixed term highway PPP contract with tolls, the concessionaire bears all the exogenous demand risk. This risk is in general beyond her control, and low realizations of demand often trigger renegotiations. In contrast, a flexible term contract, where the winning firm collects a fixed amount in user fees (in present value), eliminates demand risk borne by the concessionaire. These Present-Value-of-Revenue (PVR) contracts have a built-in renegotiation, by extending the contract term when the demand realization is low, without the need to modify the contract, thereby avoiding that source of opportunistic behavior.

Chile began using PVR contracts for most transportation PPPs in 2007 and reformed its PPP legislation in 2010. The reform created the independent technical panel that reviews and authorizes renegotiations, and requires the owners of the SPV to auction the works required by all major additions to the initial project. The combination of both policy innovations was followed by a reduction in renegotiations, as a fraction of investment, of more than 90 percent.

The remainder of this chapter is organized as follows. In section 2 we briefly review some data about global and regional PPP spending, and show that PPPs are a modest share of total infrastructure spending. Section 3 explains how current fiscal accounting practices stimulate the use of PPPs for the wrong reasons. Section 4 discusses the efficiency gains potentially brought about by PPPs. Section 5 deals with renegotiations, perhaps the main threat to the PPP model of procurement. Section 6 describes the PVR contract, which corrects many of the defects of fixed-term contracts. Section 7 concludes.

\section{PPPs around the world}

\subsection{World infrastructure and PPPs}

Governments use PPPs to procure infrastructure. ${ }^{12}$ Comprehensive figures of world infrastructure spending are notoriously difficult to obtain. Available estimates of global infrastructure and PPP spending come from a few studies by global consultancy firms and must be parsed from several studies. We now will see that available data suggests that PPP spending accounts for about 3 percent of global infrastructure spending, and 8 percent of private infrastructure spending. ${ }^{13}$

According to Airoldi et al. (2013, Exhibit 1), world public and private infrastructure spending, excluding telecoms, averaged about USD 2.7 trillion in 2008-2010. ${ }^{14}$ As can be seen in column 1 of Table 1 , spending can be broken down in transportation (USD 1,040 billion); social infrastructure (USD 490 billion), water and waste (USD 160 billion), oil and gas transmission (USD 190 billion), and electricity (USD 810 billion).

\footnotetext{
${ }^{12}$ There are variations about what classifies as infrastructure. Ports, airports, railroads and roads are almost universally included in any list and called "transport infrastructure". "Social infrastructure" includes government buildings and facilities, schools, jails and hospitals. "Energy" includes electricity (generation, transmission and distribution) and pipelines (oil and gas). "Sanitary infrastructure" includes waste management and water (production, distribution, sewerage and treatment). Finally, sometimes telecom investments (cable or fiber optic transmission, towers, base stations, fixed line and satellites) are included.

${ }^{13}$ What follows is based on Engel et al. (2014b)

${ }^{14}$ This estimate includes 69 countries which account for about 96 percentage of world GDP.
} 
Transportation, in turn, can be broken down in ports (USD 110 billion), airports (USD 80 billion), rail (USD 400 billion) and roads (USD 450 billion). Moreover, according to the consultancy Infonetics, global capex spending in telecomm was about USD 300 billion in 2011. Hence, yearly global infrastructure spending is about USD 3 trillion, around 5 percentage of world GDP.

Table 1: World Infrastructure Spending and PPPs, 2008-2010, Annual, USD Billions

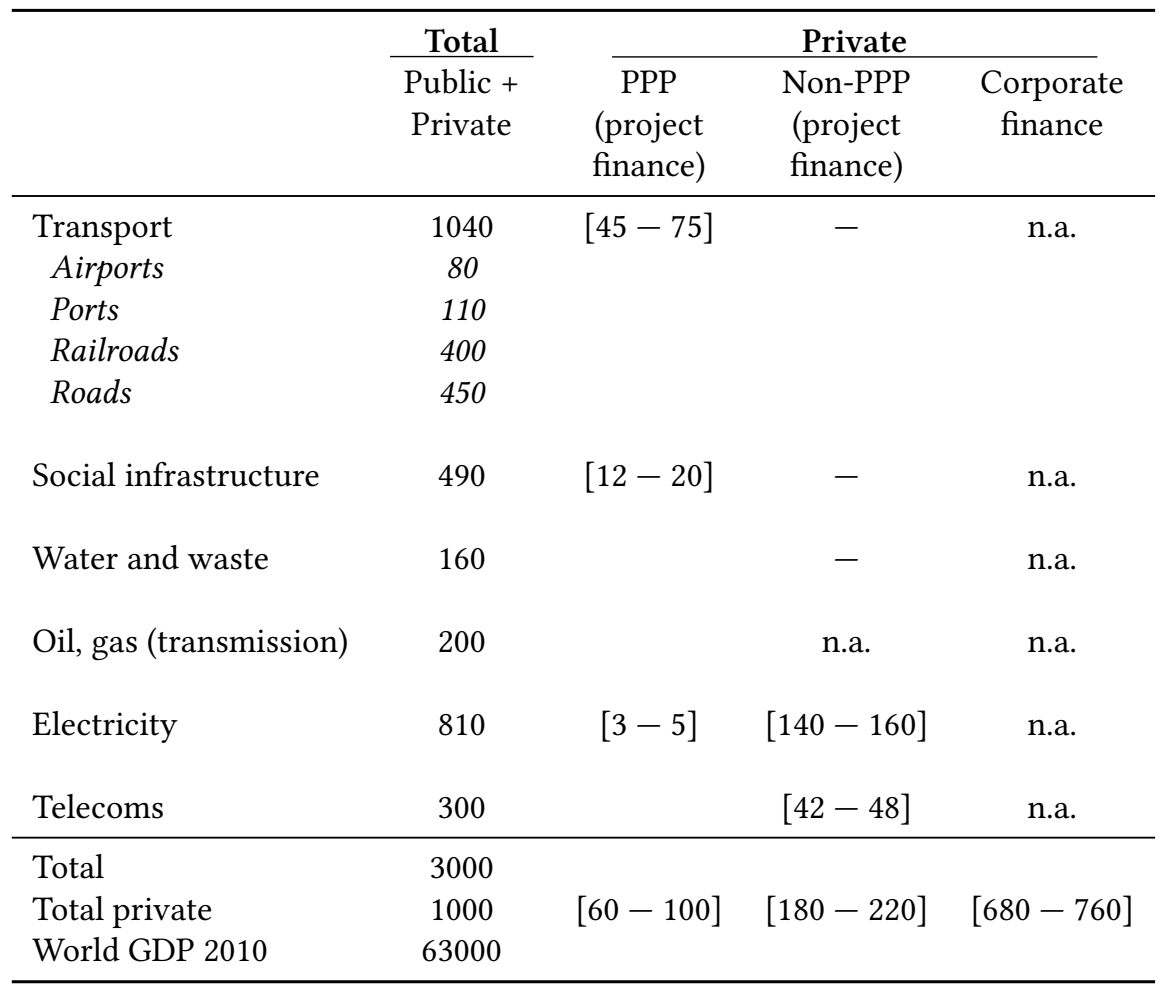

Also according to Airoldi et al. (2013, Exhibit 1), private infrastructure spending is about one-third of total infrastructure spending. With some extrapolation to telecoms, this implies that private spending in infrastructure is about USD 1 trillion. Private infrastructure is funded through PPP project finance, through other project finance and by standard corporate finance. We have not found a breakdown of private infrastructure investment by type of infrastructure.

Estimates of PPP investment are rather sparse. We built the following estimate, reported in column 2 of Table 1, with information from Inderst (2013) and Blanc-Brude and Ismail (2013). Note that most PPPs are financed with project finance. According to Inderst (2013), who cites Dealogic (2013), total project finance around the world in 2012 was USD 382 billion-total project finance for infrastructure projects varies between USD 280 billion and USD 320 billion. According to Inderst (2013, p. 24), PPPs represent between USD 60 billion and USD 110 billion per year of project financs.

It can also be seen in Table 1 that around 75 percent of PPP spending is in the transport sector, that is, between USD 45 and USD 75 billion per year. Another 20 percent of PPP spending finances government services (between USD 12 and USD 20 billion per year), while the remainder (between USD 3 and USD 5 billion per year) is invested in the electricity, telecoms, and water and waste sectors. It follows that PPP spending is only a small fraction of global infrastructure spending: around 3 percent of total world 
infrastructure spending and around 8 percent of private infrastructure spending.

\subsection{PPPs in Europe and developing countries}

Both PPP spending and the number of projects are relatively small, and for that same reason, both the composition and size of PPP investment varies from year to year. To gain some perspective about recent developments in PPP spending, we present some data from Europe and from developing countries.

\subsubsection{Europe}

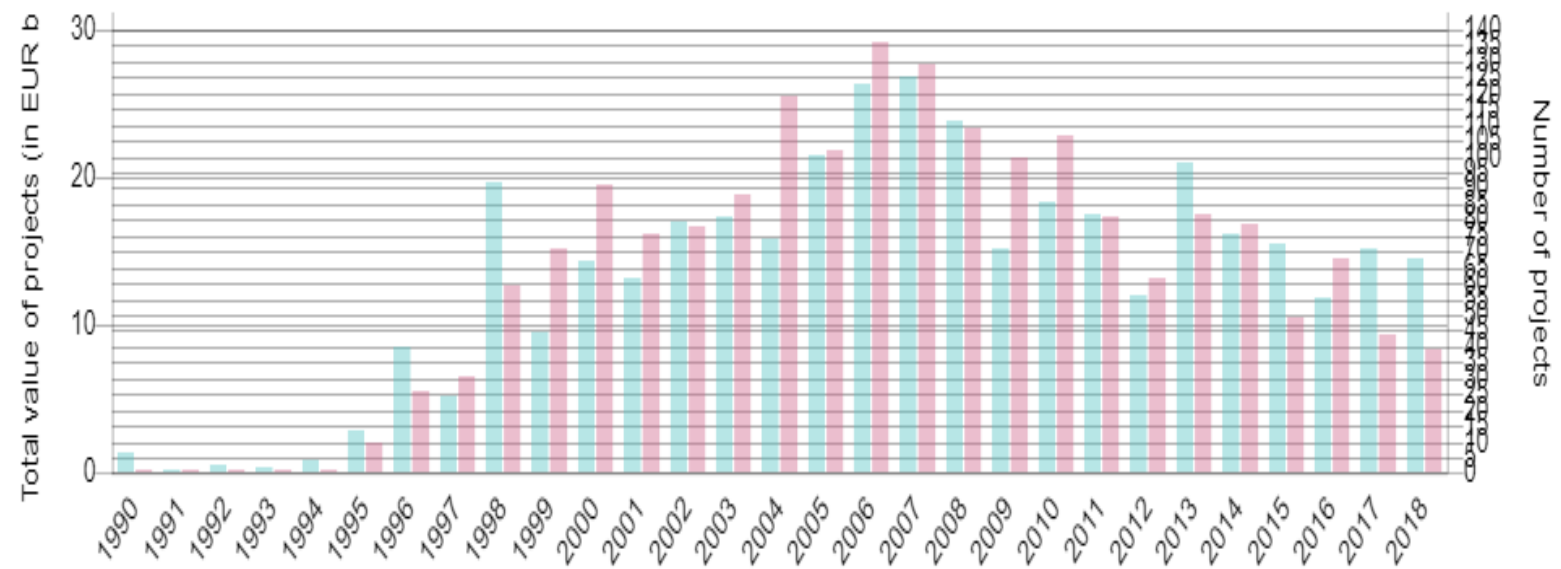

Year

Total value of projects $\square$ Number of projects

Figure 1: Number and Value of PPP projects in the European Union. Source: https : / data . eib . org/ epec/sector/all.

In the European Union, infrastructure PPPs emerged in the 1990's and grew until the 2008 crisis, peaking at $€ 26.8 \mathrm{~B}$ in 129 projects in 2007. Since then the number of projects fell, and in 2018 there were 39 projects worth $€ 14.6 \mathrm{~B}$, see figure 1 .

All in all, since the 1990s 1,841 PPP projects were undertaken in the entire European Union, valued at $€ 383.2 \mathrm{~B}$. ${ }^{15}$ The average project value of $€ 480 \mathrm{MM}$. As can be seen in figure 2 , which decomposes the value of projects by sector, more than half of the investments ( 54.8 percent) were in roads (391 projects of about $€ 500 \mathrm{MM}$ on average), followed at a big distance by healthcare (393 projects of about $€ 129 \mathrm{MM}$ on average) and 443 education projects, with an average investment of $€ 81 \mathrm{MM}$.

However, these investments are a small fraction of EU investments in infrastructure. The European Economic Association (EEA), the EU plus Switzerland, Norway, Iceland and Lichtenstein and Croatia, records investments in transport infrastructure. During the period 1995-2014, average annual EEA road infrastructure investment was €62.5 B. Considering all transportation sectors (road, rail, inland water sea

\footnotetext{
${ }^{15}$ Source for the data in the paragraph: https : //data.eib.org/epec/sector/all.
} 
t

Total value of European PPP projects by sector - all countries

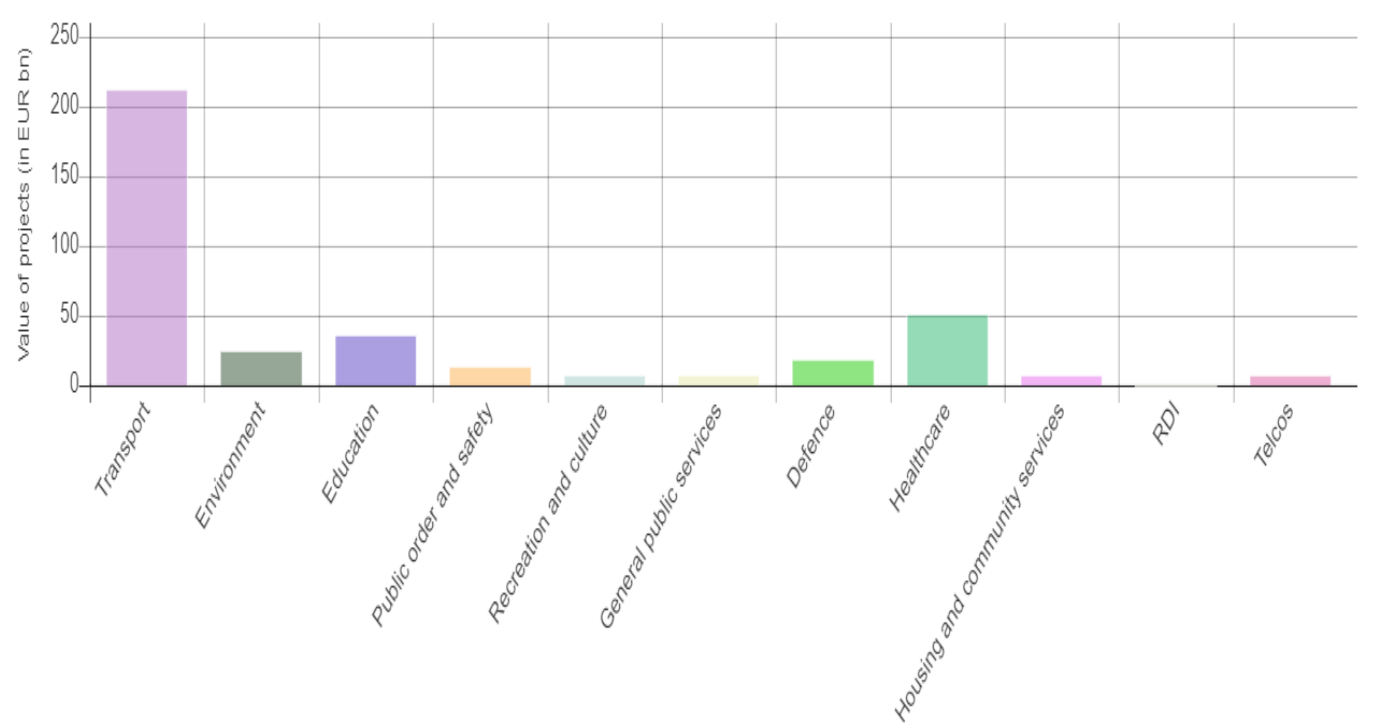

Figure 2: Value of PPPs by sector 1990-2918. Source: \https ://data . eib. org/epec.

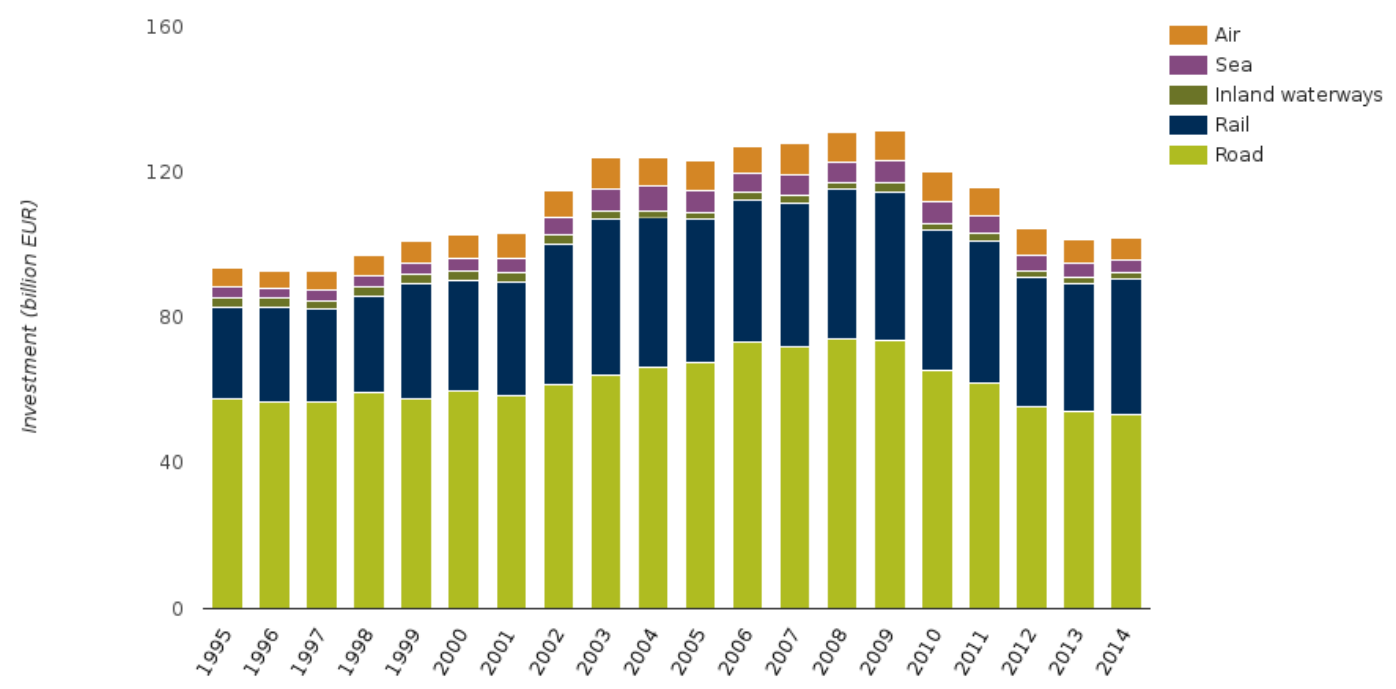

Figure 3: Investment in Transport Infrastructure EEA. Source: https : / /www . eea . europa . eu/ data-and-maps/indicators/infrastructure-investments/assessment-3 
and air) this average increases to $€ 111.5 \mathrm{~B}$. Transport PPPs represent 9 percent of transport investment in the EU. For Europe, PPPs are a complement and not the main source of transport investment.

Notwithstanding their small proportion of total infrastructure expenditure, in some of these countries PPP projects represented substantial additions to the transport infrastructure. For instance in Portugal, between 1999 and 2008, 1,300km of highways were built using PPPs. Since before1999, Portugal only had $2,000 \mathrm{~km}$ of highways, this represented a 65 percent increase in the highway stock in 9 less than a decade. ${ }^{16}$

\subsubsection{Developing countries}

The Private Infrastructure Advisory Facility (PPIAF) keeps a database of PPP projects in developing countries, classified by type of investment (transport, energy, telecom and water and sanitation related). Between 1990 and 2018 there were 1,762 transport projects (Railroads, Roads, Ports and Airports) for a combined investment value of USD 535 billion. The average project size in the case of roads was USD 287MM, close to the project average of USD 304B. Figure 4 shows the evolution of the PPPs in value as well as in number of projects. ${ }^{17}$

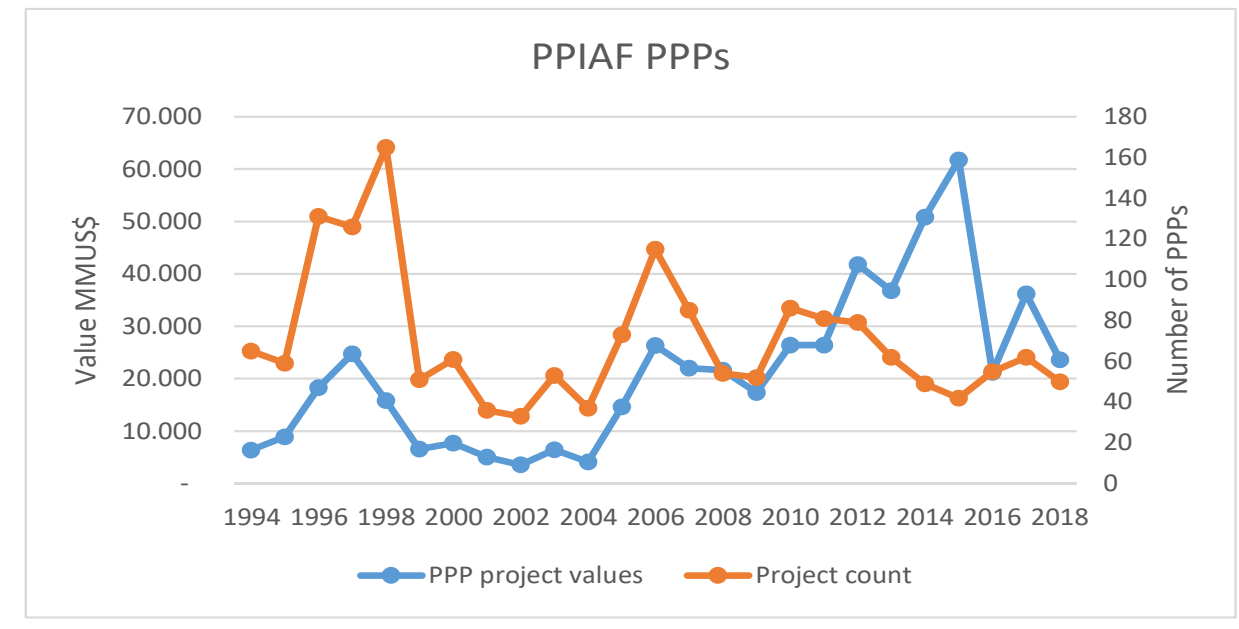

Figure 4: Evolution of the number of PPP projects and their value, developing countries

The relative importance of the different sectors of PPP transport investments in developing countries are shown in table 2. Roads represent around half of projects and investments in transport PPPs. Ports represent the smallest investment on average, because in most cases the PPP consists of an operational

\footnotetext{
${ }^{16}$ Major highway growth in Portugal, March 2010, Highways Routes du Monde, http : //www . worldhighways . com/ sections/eurofile/features/major-highway-growth-in-portugal/.

${ }^{17} \mathrm{We}$ include projects only when they reach financial closure, which explains why the data runs from 1994 to 2018 (half year). PPPIAF includes projects with private participation that are not PPPs. These amount to 310 projects worth US\$46B, i.e., less than 10 percent by value.
} 
franchise and the requirement of investing in new equipment. Usually they do not include new port infrastructure. In the case of airports, with a very high average project value of 670MM, the average is raised by two outliers, the US\$35B IGA airport in Turkey and the combined US\$20B in the Guarulos (Sao Paulo) and the Rio de Janeiros' airport, both in Brazil. In fact, the median project size is far smaller than the average size in the case of airports.

Table 2: Number and investment in PPPs by sector, developing countries

\begin{tabular}{|c|c|c|c|c|c|}
\hline Sector & Projects & Total Investment (MUS\$) & Avg. Project Size MUS\$ & $\%$ of PPP Investment & $\%$ of projects \\
\hline Airports & 142 & 95.085 & 670 & 17,8 & 8,1 \\
\hline Roads & 921 & 264.219 & 287 & 49,4 & 52,3 \\
\hline Ports & 469 & 69.839 & 149 & 13,1 & 26,6 \\
\hline Railways & 228 & 105.601 & 463 & 19,7 & 13,0 \\
\hline Total & 1760 & 534.744 & 304 & 100,0 & 100,0 \\
\hline
\end{tabular}

\section{Why governments use PPPs: Fiscal accounting}

In many, if not most cases, PPPs have been attractive to policy makers because they promise to relax the fiscal constraints that limit resources for infrastructure projects. The government can build schools, hospitals, roads and airports without their cost representing an increase in fiscal deficits. A second reason is that often PPPs coincide with political preferences for an increase in the scope of the private sector. ${ }^{18}$

\subsection{PPPs as a means of evading fiscal spending constraints}

As mentioned in the introduction, PPPs investment is not considered to be part of the fiscal deficit. This is true even when the PPPs involve periodic payments to the private party. Thus governments that are fiscally constrained may find it an attractive way of evading these constraints to indulge in politically attractive infrastructure spending. In fact, this seems to have been the main incentive for the use of PPPs in Europe. In the UK, the Private Finance Initiative (PFI), led to increases in public investment that were not recorded in the standard measures of public debt. ${ }^{19}$ According to the PFI and PF2 National Accounting Office (NAO) 2018 Report:

"The Office for Budget Responsibility's (OBR's) July 2017 fiscal risks report cited the use of off-balance sheet vehicles like PFI as an example of a 'fiscal illusion'” [... "The debt is recorded as a financial liability but as noted by the OBR "most public and political attention, and the government's fiscal rules, still concentrate on the National Accounts measures

\footnotetext{
${ }^{18}$ There is no agreement on whether or how to include PPPs in the public accounts and in the government's balance sheet. See Heald (1997, 2002, 2010), Grimsey and Lewis (2002), Heald and Georgiou (2011) and Schwartz et al. (2008, part four).

${ }^{19}$ As a signatory to the Maastricht Accord, the UK was required to keep its fiscal deficit below a maximum deficit.
} 


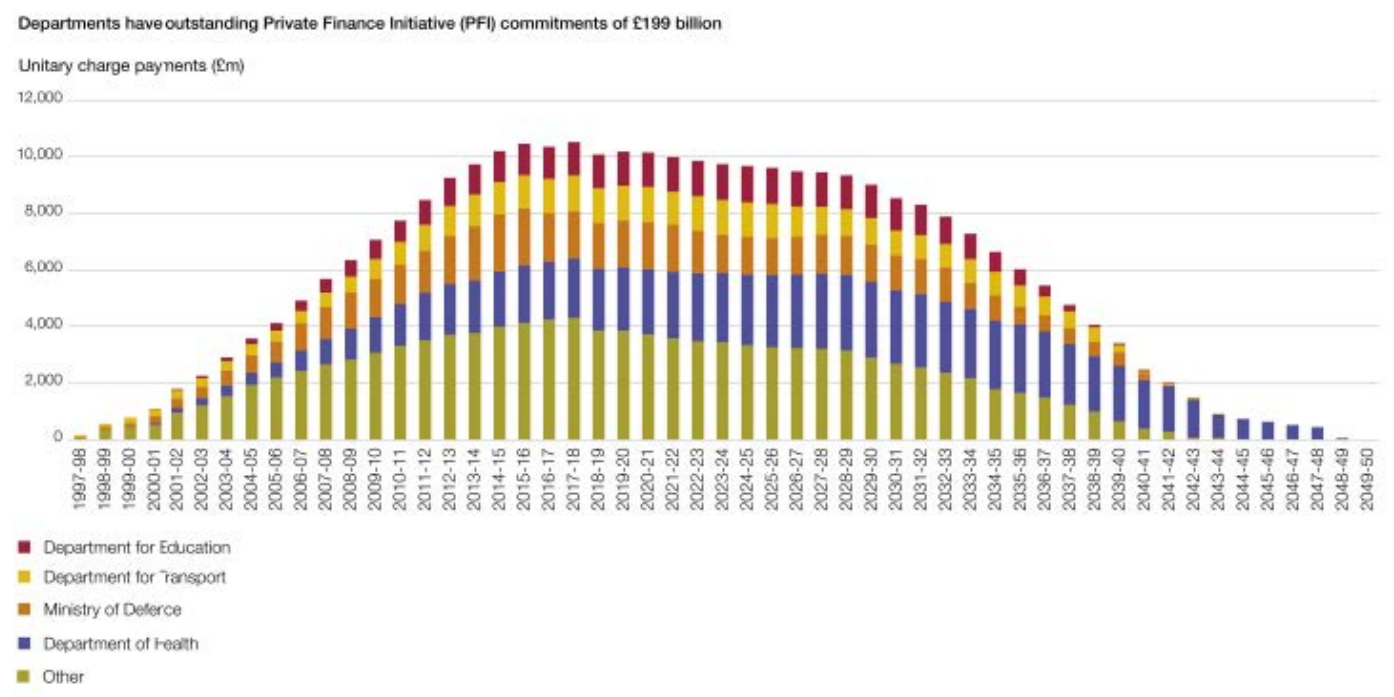

Figure 5: PFI Past and Forecast Unitary Charge Payments. Source: PFI and PF2 NAO 2018 Report

of PSND (Public Sector Net Debt) and PSNB (Public Sector Net Borrowing)," which does not reflect fully PFI liabilities. PFI can be attractive to government as recorded levels of debt will be lower over the short to medium term (five years ahead) even if it costs significantly more over the full term of a 25-30 year contract."

These policies encumbered the UK with average annual payments of $£ 7.7 \mathrm{~B}$, for the following 25 years, beginning in 2017-18, according to the NAO 2018 Report. This represents 0.5 percent of the national budget until the decade of the 30's, see figure 5. The UK invented the concept of "value for money" (VfM) to determine which projects should be built using PPPs and which ones should use public provision. However, VfM is a concept that is easily manipulated, even in a developed country such as the UK. ${ }^{20}$

Portugal received €20 billion in PPP investments in roads, hospitals and other projects in the period 1995-2014. Most of the investment was in highways that used shadow tolls (94 percent of PPP investment). The minimum guaranteed payments represents 1 percent of GDP, annualy, in 2014-2020, falling to 0,5 percent of GDP until 2030. In a study of Portuguese PPPs, Sarmento and Renneboog (2014). write that "[...] the incentive to resort to PPPs was mainly to avoid budget constraints, but not to use of public resources better by taking advantage of private sector $[\ldots]$ ".

Even the case of a PPP that charges user fees, such as a tolled road, does not represent a break from the principle that PPPs have the same effect as public provision on the intertemporal budget constraint of the government. Note that the Public Authority could have created a public Single Purpose Vehicle (SPV) which could contract a private firm to design and build the same road, charge the same tolls and generate

\footnotetext{
20"A robust VfM assessment is important for all public sector investment decisions. Any public body procuring an asset which will be privately financed has to compare the VfM of private finance against a public sector comparator (PSC). It has an incentive to show that private finance offers better value for money than the PSC as unless alternative capital funding is made available the project is unlikely to proceed. We previously concluded in our 2013 report Review of the VfM assessment process for PFI that these VfM assessments have features which favour and advantage PFI in comparison to a publicly financed approach." National Audit Office, HM Treasury: "PFI and PF2", 2018, p. 19.
} 
as much toll revenue as the private party. This SPV could have issued a bond whose repayment is tied to toll revenues, and it would in principle have access to conditions that are identical to those of the private party. ${ }^{21}$ Thus in using the PPP approach to build a project, the Public Authority is not obtaining additional resources from those it could have obtained by itself.

The advantages of PPPs must lie elsewhere, for example, in efficiency gains, as discussed in the introduction and the section that follows.

Table 3: Fiscal accounting: Funding from government transfers

\begin{tabular}{lcc}
\hline & Public provision & PPP \\
\hline Now: & Issue 100 in debt & "Save" 100 in debt \\
Now: & Spend 100 on infrastructure & Spend 100 on infrastructure \\
Future: & Collect 100 in taxes & Collect 100 in taxes \\
Future: & Pay bondholders 100 & Pay concessionaire 100 \\
\hline
\end{tabular}

We have shown (Engel et al., 2013) that the effects of PPPs on the intertemporal balance sheet are no different from those of public provision. Table 3 provides the intuition when funding comes from government transfers. The first column shows the dynamics of debt and spending under public provision, the second column under PPP. In both cases, the infrastructure that is built today comes with a commitment to collect taxes in the future, in the same amount, and therefore the initial investment should count as public debt in both cases.

Table 4 considers the case where user fees fund the project. Now, for both organizational forms, building the infrastructure entails a commitment to collect user fees in the future, in the same amount, to pay for the debt. It follows that the upfront investments should be counted as debt for a PPP as well.

Table 4: Fiscal accounting: Funding from government transfers

\begin{tabular}{lcc}
\hline & Public provision & PPP \\
\hline Now: & Issue 100 in debt & "Save" 100 in debt \\
Now: & Spend 100 on infrastructure & Spend 100 on infrastructure \\
Future: & Collect 100 in user fees & Give up 100 in user fees \\
Future: & Pay bondholders 100 & Concession collects 100 in user fees \\
\hline
\end{tabular}

Another way in which PPPs can be used to increase current expenditure occurred in the case of the Chicago Skyway, a 7.8 mile toll road linking downtown Chicago to the Indiana State line. The $\$ 1.83$ billion bid for a 99 year lease allowed the city government to retire the remaining Skyway bonds, save some funds for the future, and use almost all of the remaining $\$ 475$ million to increase current spending. The efficiency gains of the contract were minimal, being at most a reduction in operating costs of $\$ 1$ million a year (see Engel et al., 2014).

\footnotetext{
${ }^{21}$ This is perhaps not possible due to other factors, but while relevant, these indirect effects do not affect the principle that there is no direct effect of a PPP on the intertemporal budget constraint.
} 


\subsection{Distorted Policy choices}

The choice between PPPs and public provision of infrastructure is distorted because PPPs are at least partially excluded from the balance sheet. This distortion disappears if PPPs are included in toto in the balance sheet at the inception of the contract. As revenues accrue and the time at which the PPP contract ends comes nearer, the balance sheet incorporates these revenues on the revenue side. By doing this, the choice between doing a project as a PPP or as a public project is not distorted by the fact that the costs of the project are charged onto the future. In that case, choice between PPPs and traditional provision of infrastructure would depend only on which approach is demonstrably more efficient in the provision of infrastructure.

\subsection{Eurostat and fiscal accounting of PPPs}

In order to limit the unrestricted use of PPPs for unrecorded fiscal expenditure, Eurostat introduced accounting rules for PPPs (Eurostat, 2016). The new rules made a distinction between PPPs funded primarily with user fees or tolls and those PPPs funded mainly by government transfers. Eurostat considers toll funded PPPs as off-balance sheet as a general rule, unless there exist government guarantees that are deemed substantial. In contrast, the treatment of government funded PPPs seems to have been a compromise between the forces pushing for the exclusion of PPPs altogether from the government balance sheet, and those that found that it was an unsound fiscal policy, as events would show in the aftermath of the world financial crisis of 2008. The classification of a particular government funded PPP project as onor off-balance sheet depends on the answer to 84 yes-no questions divided into 11 sections. $^{22}$ In particular, there should be no mechanism, such as a government guarantee or early termination provisions, that transfers the risks back to government.

Summing up, Eurostat guidelines are ineffectual in limiting the use of PPPs to circumvent budgetary controls, as their main focus is on risk sharing, not on their budgetary implications. This has not always been the case. In the 1980s the UK used the so called 'Ryrie Rules' for PPP projects. ${ }^{23}$ They allowed private finance of public infrastructure only be used if public expenditure was reduced by the same amount. These rules were abandoned under the PFI program of the mid 90s.

\section{Economic arguments for PPPs: Incentives, risk and efficiency}

\subsection{Efficiency}

PPPs are a response to the perceived shortcomings of traditional provision of government infrastructure. It is important to recognize this point of departure, for it confirms that PPPs are a different way of procuring infrastructure, not a form of privatizing government assets and functions.

\footnotetext{
${ }^{22}$ For example, question 70 asks "does the (private) partner bear the construction risk and at least one of either the availability or the demand risks?.' If the answer is 'no', the asset is classified on the government's balance sheet. If the answer is 'yes', additional conditions must be met for the asset to be kept off the government's balance sheet.

${ }^{23}$ See Heald and McLeod (2002) for an insightful discussion of the Ryrie rules. Maskin and Tirole (2008) provide a model for how PPPs are used to elude budgetary constraints.
} 
With traditional provision, incentives tend to be weak, because public agencies have multiple objectives and principals, fiscal accounting practices are not the right tools to monitor performance, and earnings do not reward employees and owners. Moreover, laws and the legislature constrain hiring, purchasing amd contracting practices, and the organizational and management structure of the organization is determined by statute. Finally, the scale and scope of the organization that manages projects is set largely by the exogenously given administrative structure of the government, not by any efficiency consideration or regard for the optimal scope of the organization.

The consequences of poor incentives are also well known. The infrastructure assets are poorly maintained, because budgets are subject to yearly appropriations, maintenance expenditures are less visible than new works, and sometimes poor design and construction increases the cost of maintenance. Consequently, the quality of service in general tends to be low. In addition, project selection tends to be poor, both because demand is systematically overstated, and because costs and building times are underestimated (Flyvbjerg, 2003). Worse, pork barrel projects and poor planning often build white elephants.

Subcontracting tasks to private firms has been the main means whereby private incentives were brought into public provision. PPPs represent a different organizational form that goes beyond hiring contractors to build a project. Under a PPP, the private concern creates a private entity-a so called special purpose vehicle or SPV- in charge of financing, delivering and operating a public project. While the relation between the state and the SPV is still governed by public law, the SPV is a private firm and its contracting relations with employees, other firms, and financiers are governed by private law. This improves incentives, because during the term of the PPP, the SPV has discretion to manage the infrastructure as a private firm. Moreover, by creating an SPV, the scope of the firm is clearly defined and limited, and the project gets a dedicated management team, which answers to the SPV board.

The literature also notes that a PPP is an intertemporal contract between the government and a private firm which bundles finance, construction, maintenance, and operations. Hart (2003) has shown that the theoretical benefits brought about by PPPs arise in part from bundling design, building, operation, and maintenance. The reasoning is that since the concessionaire will operate and maintain the project, it will design and build it to minimize life cycle costs. Moreover, provided that the quality of conservation can be measured and required by the contract, it is in the interest of the concessionaire to maintain the infrastructure continuously.

Bundling, however, introduces a basic trade off, identified by Hart (2003): other things equal, it stimulates investments and actions that cut life-cycle costs and other costs more generally. Nevertheless, this cost cutting may occur at the expense of service quality and user welfare; this is commonly known as "Hart's tradeoff." Thus, there is a strong presumption that PPPs will work well only if maintenance, quality and performance standards can be described clearly in the contract and can then be enforced. This is the case of roads, for example.

The theoretical advantages of bundling have proven difficult to test, but the benefits in terms of maintenance are clear. As we have already mentioned, governments often do not perform regular, continuous maintenance because the effect of the resources that are used is not salient to the public. There are more politically attractive uses for these resources: completely new infrastructure projects, or the repairs of 
severely deteriorated infrastructure. In both cases, the benefits are obvious and contrast with the lack of perceived benefits from routine maintenance. On the other hand, a PPP owner is very interested in routine maintenance if quality standards are enforced. The firm is aware of the increased costs of reactive maintenance and of the penalties associated to insufficient maintenance and will manage the project so that it is correctly maintained at all times. As mentioned in the introduction, continuous maintenance of a highway not only provides considerably better quality of service but also is much cheaper.

There is some anecdotal evidence that PPP projects tend to be delivered on time, which suggests stronger performance incentives. For example, Raisbeck, Duffield and Xu (2010) found that in a sample of 21 PPP projects and 31 traditional projects in Australia, the time "between the signing of the final contract and project completion, PPPs were found to be completed $3.4 \%$ ahead of time on average, while traditional projects were completed $23.5 \%$ behind time." Indeed, if the firm starts to receive revenues only when the project starts to operate, there is a cost to delays, and an incentive to finish construction as fast as possible. In the particular case of fixed term contracts financed with user fees, this incentive is even stronger, because delays in construction cut into the revenue generating period. On-time delivery also requires better planning, project design, and execution, all of which may lead to reduced cost overruns. ${ }^{24}$

Even under PPPs, the government is responsible for planning what to build (network planning and coordination), whether a particular project should be built (cost-benefit appraisal), and when it should be built. In addition, there are arguments for and against delegating project design to the concessionaire. The argument in favor of delegating design is that it takes advantage of the creativity of the private sector and transfers design risk to the concessionaire. But the case can be made that governments who delegate project design tend not to have a full understanding of the projects they procure in the first place, nor of the risks they confront. The relevant point here is that it is unlikely that delegating project planning to the concessionaire will systematically increase productive or dynamic efficiency. A case can be made for collaboration between the two parties in improving a government designed project after the bidder has been selected in a competitive process. ${ }^{25}$

Two additional sources of efficiency gains appear when the PPP is financed with user fees. First, the transfer of resources to the private firm is direct. In contrast, in a publicly funded project, the resources for construction, maintenance and operations are collected through taxes, and wend their way through the government bureaucracy, until eventually they reach their destination in the private firm that performs those tasks. The direct approach eliminates the costs associated to this bureaucracy. The second benefit is that tolling can be used to deal with congestion and increase allocative efficiency. In a congested highway, the marginal cost should include the congestion externality. Moreover, given that the taxes used to provide a free publicly provided highway create distortions, it might well be that a PPP with user fees is more efficient globally than a free publicly provided road with a larger congestion externality. In fact a globally

\footnotetext{
${ }^{24} \mathrm{~A}$ rule of thumb in construction says that if the project is delayed, outlays in materials and labor directly employed in construction are postponed as well, but overheads continue to be incurred. A second rule of thumb says that overhead is roughly one-third of the yearly and total cost of a project. Thus if $\mathrm{T}$ years is the estimated duration of the project and yearly outlays are equal to 100 , then an delay of $t$ years creates an overrun of the order of (100t/3T). Thus, delays create cost overruns. Source: Klaus Grewe, personal communication.

${ }^{25}$ An alternative auction process for complex projects is for the government to assign the project to the best project for purpose, given the resources announced for the project.
} 
optimal fiscal policy would set tolls slightly higher than the optimal congestion toll, because by so doing the government can reduce distortionary taxation elsewhere (see Engel et al. 2013). ${ }^{26}$

\subsection{Incentives and risk allocation}

Risk allocation is one of the main functions of the PPP contract. Following Irwin (2007) we can classify risks into eight categories: (a) construction risk, including design flaws, cost overruns, and delays; (b) operation and maintenance; (c) availability under the terms agreed in the contract; (d) residual value at the end of the PPP contract; (e) policy, ranging from macroeconomic uncertainty to government actions that affect the project; (f) demand; (g) financial (e.g. interest rate and exchange rate fluctuations); and (h) political (e.g. regulatory takings or expropriation).

Irwin (2007, p. 65) states the principles that should be used to assign each risk: allocate them to maximize project value, considering each party's ability to influence, anticipate, and absorb risk (and transaction costs). This implies risks should be borne, at least in part, by the party best equipped to control them. At the same time, an exogenous risk should be shifted to the party best endowed to bear or diversify it.

Consider construction risk. The builder controls the time to complete the project, and the cost of building it. The concessionaire should thus bear these risks, perhaps with the exception of delays caused by disputes about the application of eminent domain. Similarly, because diligence during construction influences the availability of the facility during operation, it is efficient for the concessionaire to bear operation, maintenance cost, and service quality risk.

Bundling, control, and service standards are all required to ensure that these risks are effectively borne by the concessionaire. For example, it may be harder (i.e., more expensive) to make a concessionaire responsible for service quality if it was not responsible for building the facility (hence the importance of bundling) or if the concessionaire has no control over investment and operational decisions (hence the importance of control, or ownership, rights). Similarly, without objective and measurable service standards, it is difficult to transfer service quality risk to the concessionaire.

As Hall (1998) points out, risk allocation depends in part on how the concessionaire is remunerated. As mentioned above, to create strong incentives to complete the project on time, the firm should receive payments only after the facility starts to operate. Similarly, availability payments which are contingent on meeting service quality standards generate strong incentives for adequate maintenance and performance. By contrast, when payments do not depend on performance or, worse, the firm can transfer cost overruns to taxpayers, PPPs reproduce the weak incentives of public provision.

Some of the risks are created by government policies. Because the residual value of PPP assets depends on government planning decisions (not to mention that most assets are project specific), and the willingness to charge tolls in future concessions, it is sensible to transfer the residual value risk to the government. This happens when the concessionaire recovers its initial investment over the term of the contract, and then transfers the residual value to the government. This principle suggests, as well, that an effcient policy would have some policy risks borne by the government, so as to reduce its own moral

\footnotetext{
${ }^{26} \mathrm{~A}$ final advantage of PPPs financed by user tolls is that the private firm may be less responsive to petitions to lower user fees than a publicly elected official.
} 
hazard.

Broadly speaking, policy risks fall into two categories. First, the government may implement policies that directly affect the project and have few other effects. For example, it may change the rules to expropriate the concessionaire. These principles indicate that these risks should be borne by the government, to prevent opportunism. Second, actions by the government or the legislature may unintentionally affect the PPP. For example, currency devaluation may reduce a foreign firm's return, or a change in environmental standards may require additional investments. In these cases, the concessionaire is in the same position as any other private firm in the economy. Therefore, these are standard business risks. This principle is routinely overlooked. ${ }^{27}$ For example, governments often grant foreign concessionaires insurance against devaluations. Not only does this discriminate against local investors, but it also discriminates against foreign firms in other sectors of the economy that bear this risk. More generally, policy risks that do not target the project specifically and that affect most firms in the economy (for example, those caused by monetary policy) should be treated as exogenous and allocated according to general principles of risk diversification.

Perhaps the main exogenous risk in a PPP project financed by user fees is uncertainty about demand. As mentioned above, the general principle is that exogenous demand risk should be borne by the party best able to bear it. If the private firm assumes demand risk, taxpayers are in fact purchasing an insurance contract on an exogenous risk that they assume under public provision (see Engel et al. 2014a, chapter 5). As Hall (1998) notes, this is not cost effective. Demand forecasts are notoriously imprecise and changes in policy, which are unknown at the time of tendering, may radically affect the usage of the facility, yet there is little that the firm can do about it. Even the design of the project is usually determined by the government. In those cases, either a present-value-of-revenue contract (see section 6) or an availability contract are the appropriate compensation scheme, depending on whether the main source of funds are user fees or government transfers.

The principle of transferring exogenous demand risk to the government admits one important exception. When user fees are a PPP's only source of remuneration, the willingness of private firms to bid for the contract is a market signal that demand is sufficient (at least in expectation). This introduces a market test that is usually absent in infrastructure services and that helps to avoid white elephants. If there are no bidders at an auction, this is a signal that the project is not privately profitable and therefore there is a risk that the project is a white elephant unless it has large positive externalities.

As in the case of demand risk, financial risk is largely outside the firm's control. This does not mean, however, that the government should bear interest rate or exchange rate risk. Other firms in the economy do not receive this favoured treatment, and firms can choose among alternative capital structures. More generally, governments are not particularly efficient at providing and selling financial insurance.

\footnotetext{
${ }^{27}$ García-Kilroy and Rudolph (2017) argue that governments should offer currency risk sharing arrangements, when financial markets fail to do so. They describe experiences where this has been done, at a price close to what would have been a market price..
} 


\section{Governance and renegotiations}

Given the often unsatisfactory results of PPP programs in infrastructure, it is worthwhile to study whether this is due to difficulties in the governance of PPPs. At a minimum, a PPP-capable country requires a level of institutions that allow private parties to invest large amounts in sunk projects in the expectation that they will receive a return. In particular, it requires that the revenue stream associated to the project can be pledged to third parties and that they are first in line if the SPV associated to the PPP fails. Furthermore, there has to be a reasonable expectation that the investment cannot be expropriated without compensation. These conditions may preclude PPP investment in some countries. ${ }^{28}$

However, even in countries that satisfy these minimal requirements, there is no guarantee that an infrastructure PPP will be successful. We deal with some of these problems in this section.

\subsection{Renegotiations are pervasive}

PPPs are routinely renegotiated. This has been well known since Guasch (2004) examined nearly 1,000 Latin American concession contracts awarded between the mid-1980s and 2000, and found that 54.4 percent of those in transportation (including roads, ports, tunnels, and airports) had been renegotiated. When Mexico privatized highways in the late 1980s, Mexican taxpayers had to pay more than US\$ 13 billion after renegotiation of the initial contracts. In Chile, 47 out of the 50 Chilean PPP concessions awarded by the Ministry of Public Works between 1992 and 2005 had been renegotiated by 2006, and one of every four dollars invested had been obtained through renegotiation (see Engel et al., 2009b). More recently Engel et al. (2019a) analyzed 535 renegotiations of 59 highway PPPs in Colombia, Peru, and Chile. Renegotiations per concession/year average 9.5 percent of the initial investment in Colombia, 3.6 percent in Peru, and 1.3 percent in Chile. More than 45 percent of renegotiations (by dollar amount), occur during construction. And at least 60 percent of the renegotiated spending increase falls on future administrations. ${ }^{29}$

One might think that renegotiations occur mainly in emerging economies, where governance is weak. They are also pervasive in developed countries, however, as documented long ago by Gómez-Ibáñez and Meyer (1993). For example, three of the four highway concessions awarded in France in the early 1970s went bankrupt after the 1973 oil shock and were bailed out by the government. Similarly, several of the twelve highway concessions awarded in Spain in the 1970s had higher costs than anticipated, while traffic

\footnotetext{
${ }^{28}$ Or if it exists, it must be supported by multilateral financial institutions, see Engel et al. (2014a).

${ }^{29}$ Renegotiations are not only common in transportation infrastructure. An example from the sanitation sector are the two concessions for water utilities in Manila, Phillippines, in 1997. As noted in Wu and Malaluan (2007), the state owned utility was divided geographically into two companies serving the city, and put up for auction of 25 year concessions. The two winning consortia offered tariffs that were 26 and $56 \%$ of the previous rates. However, by 2002 they had managed to renegotiate their contracts and double the prices (using the Asian crisis as an argument), and then almost doubled them again in 2005. Moreover, the companies invested less than specified in their contracts, at least until 2003, when Manila Water began to expand investment rapidly, perhaps because after the change in tariffs the implied rate of return on assets rose to $9 \%$. Despite this, due to bad management, the other company, Manilad, went bankrupt (in 2003) after its petition for even larger tariff increases were denied. Regardless of the adverse effects of raising rates, there were compensating benefits from privatization: a massive expansion in connections by $30 \%$ in the first five years of operation, and in Manila Water, non revenue water (lost to theft or because of leaking pipes) decreased from almost $58 \%$ to $35 \%$, while the response to service complaints and the time to repair leaks improved substantially. We can conclude from this case that unless precautions are taken, the bids of companies can be renegotiated to the advantage of the winners at the expense of the public, but in some cases even then the public can benefit. For a more critical evaluation see Esguerra (2003).
} 
was lower than expected, causing three highways to go bankrupt and the remaining contracts to be renegotiated. Spain seems to be a serial subsidizer of PPPs at the expense of the public: in November 2010, all political parties agreed that it was necessary to bail out, among others, the seven PPP highways running into Madrid (see Engel et al., 2018b).

Industry participants often claim that circumstances change over the life of a concession. Because most PPP contracts last for several decades, renegotiations of inherently incomplete contracts are to be expected. Renegotiations thus provide the flexibility necessary to adapt to changing conditions. While there is some truth to this argument, it ignores two disturbing features of most renegotiations. First, they often occur shortly after contracts are awarded. For example, Guasch (2004, p. 14) finds that the average time to renegotiation was only 2.2 years after the concession was awarded, and 60 percent of all renegotiated contracts had been renegotiated within the first three years after the concession award. Engel et al. (2009) show that 78 percent of the amounts awarded in renegotiations of PPPs in Chile were brokered during construction, shortly after the concession was awarded. ${ }^{30}$

Second, renegotiations tend to favor the concessionaire. For example, Guasch (2004) finds that twothirds led to tariff increases, 38 percent to extensions of the concession term, and two-thirds to reductions in investment obligations. In the case of Chilean PPPs, we find that most renegotiations imply paying more for the works than originally contracted. Thus, while in principle renegotiations may allow governments to expropriate concessionaires after they have sunk their investment, in practice it seems that the private partner benefits the most, at least in Latin America. ${ }^{31}$

\subsection{The origin and consequence of renegotiations}

The prevalence of renegotiations suggests that they are not accidents, but an equilibrium outcome of the incentive structure in place. There are at least four economic mechanisms that produce systematic renegotiations.

One is related to the political cycle. In Engel et al. (2019c) we show that the possibility of being ousted from office increases the effective discount rate of the incumbent, who values the future less than the social planner and wants to anticipate spending and increase the probability of winning an election. Because fiscal accounting rules keep PPPs off balance sheet, the incumbent can renegotiate the PPP contract to increase current infrastructure spending. The concessionaire, in turn, is willing to renegotiate the contract because he is backed by a long-term legal agreement that is binding on future administrations. This mechanism works independently of how the PPP is funded. With availability payments (as is the case, for example, with many highways in Europe), renegotiated payments will be borne by future administrations and constrain their ability to spend. If, on the other hand, the infrastructure is funded with tolls, future governments will forego revenues (see Engel et al. 2013). Whatever the funding source, the incumbent can tie up resources that would have been available to future administrations, in exchange for current infrastructure spending by the concessionaire. In essence, therefore, in a renegotiation the concessionaire lends

\footnotetext{
${ }^{30}$ For more on renegotiation of PPP contracts, see Guasch et al. (2007, 2009).

${ }^{31}$ For evidence on renegotiations of US PPPs that benefited private firms at the expense of taxpayers and users, see Engel et al., 2011.
} 
to the incumbent in exchange for payments by future administrations. The incumbent's commitment is credible because the concessionaire has a long-term contract with the State, not only with the incumbent administration.

Even though there is no systematic evidence on the frequency of renegotiation of infrastructure provided under the traditional approach, the above argument suggests that renegotiations should be less frequent in this case. Since the relation between government and the firm exists only during the construction period, there is less time for the firm to find arguments to renegotiate the contract. It is also more difficult to add additional works because it would incur additional expenditures that must be approved by the legislature.

Renegotiations also generate adverse selection, by attracting firms that are better at renegotiating and skilled at lobbying, but technically less proficient. Since renegotiations between the concessionaire and the government are bilateral, surpluses are split according to the relative bargaining abilities of each. A better lobbyist should get a larger fraction of the pie in any renegotiation. Hence, if two firms are equally efficient, the firm with a better lobbyist can bid by less at the competitive auction and win the concession, in the expectation that in a later opportunistic renegotiation it can recover from having bid less.

As formalized in Engel et al. (2019b), in the competition for government contracts, firms that are worse in both aspects-technical efficiency and the ability to renegotiate-do not survive. They cannot compensate lower technical efficiency with the possibility of higher revenue from renegotiation. It follows that the firm with the highest degree of technical efficiency will also employ less skillful renegotiators, since they will not have to renegotiate to compensate for inefficiency. The implication is that if a substantial part of profits are made in the renegotiation stage, less efficient firms will have an advantage. Hence by self-selection, efficient firms should be attracted to countries in which there is little renegotiation of the initial contract, while countries that renegotiate more will attract technically less proficient firms.

The third mechanism at work is moral hazard. As we have seen before, PPPs are appropriate when objective quality standards can be set, measured, and enforced. In that case, the concessionaire can be left to choose the production technology, and the cost-cutting incentives will be equivalent to those under a fixed-price contract or a price cap. In practice, however, private firms foster the belief that PPP contracts should be adjusted to secure the financial equilibrium of the concessionaire, an argument that firms often produce to justify renegotiations (among many examples, this was the case for the bailout of Spanish PPPs mentioned above). This is not an acceptable argument for a renegotiation of the contract. If the firms' bids were prudent, the company should expect to receive the normal return on investment after adjusting for risk, as in all other sectors of the economy. Hence, the conditions of the bid should be preserved, and there should be no renegotiation that results in a higher cost of providing the contracted service quality. Renegotiations are not only unnecessary, but also inefficient, because they weaken the incentives to control and reduce costs, thereby dampening the efficiency gains that PPPs can yield. Renegotiations meant to restore the concessionaire's financial equilibrium transform a fixed-price contract into a cost-plus contract. Even worse, since firms with strong renegotiation skills can extract more from the government, they can afford to exert even less effort to control costs. Thus, moral hazard increases the advantage held by good renegotiators even further and worsens the adverse selection problem. 
Similarly, when the PPP agency has discretion to renegotiate, it feels less pressure to plan and design projects carefully, because it can renegotiate away its own mistakes. The problem is compounded when the costs of renegotiating can be shifted to future administrations and when the PPP agency is not accountable. Thus, when coupled with inadequate accounting or governance, the expectation of renegotiations generates moral hazard in the PPP agency.

Last, recent evidence from Latin America shows a connection between renegotiations and corruption. Campos et al. (2019) consider all projects undertaken by the Brazilian conglomerate Odebrecht in eight countries over a ten year period and find that the average renegotiation, as a fraction of the initial investment, was 71 percent for projects where bribes were paid, compared with 6 percent for projects were bribes were not paid. The projects they consider include both PPPs and traditional provision, suggesting that the connection between corruption and renegotiations is relevant when providing public infrastructure in general. Campos et al. (2019) also show that firms pay bribes to obtain better deals when the contract is renegotiated, as well as more frequent renegotiations.

\subsection{Governance and remedies}

The common threads behind renegotiations are inadequate rules and governance that foster lowballing in the auction, in the expectation of obtaining rents in bilateral bargaining. The remedies combine proper accounting rules, competitive tendering for additional works, and independent review of renegotiations.

As shown by Engel et al. (2019a), treating PPPs as regular government expenditure and debt eliminates the incentive to use renegotiations to increase current infrastructure spending and burden future administrations.

The remedy to the problems generated by adverse selection and moral hazard is to eliminate economic rents that are bought about by bilateral renegotiations. On the one hand, this would require the application of the so-called sanctity-of-the-bid principle (Guasch, 2004), that is, the concessionaire's bid caps the compensation that the concessionaire can obtain for the tendered infrastructure. A possibility is that additions to the original works are auctioned to the lowest bid and the concessionaire cannot participate. In addition, an independent review of the renegotiation by an expert panel could help to ensure the value of the project for the concessionaire does not change. The box below describes panels of this sort in the UK and Chile. Finally, transparency suggests that all contract modifications be published in a web page, so that the public is informed about the changes and can question the reasons and amounts. By itself, the publication of the modifications and their value is politically costly and therefore tends to harden the negotiating position of the Public Authority.

\section{Dispute Resolution in the UK and Chile}

In the UK, the framework for dispute resolution is set up in the HM Treasury "Draft Standardization of PF2 Contracts" of December 2012. The document sets up a tiered structure of procedures that starts with a consultation between the parties for a fixed period in an attempt 
to reach a mutually satisfactory agreement. If this consultation approach fails, the parties can put their case before an expert adjudicator, selected from a panel, or alternatively, to mediation or conciliation. If either party believes the decision is not acceptable, they can apply to an arbitration procedure or eventually, the courts. Akinbode and Vickers (2017). show how these procedures can escalate and how badly defined contracts can close out reasonable options of solving the conflict.

In Chile, the 2010 reform to the PPP Law established the Technical Experts Panel (TEP), a permanent, independent board of legal and engineering experts that reviews technical disputes between the contracting authority and the private party (usually an SPV). The TEP hears the parties in public audience and issues a recommendation within 30 days. Even though the recommendations are not binding, in $40 \%$ of the cases, the parties have agreed to the recommendation. The remaining cases proceed to mandatory arbitration, where the Panel recommendation is considered in the decision.

Chile reformed its PPP law in 2010 and established a Technical Experts Panel (see the box above for details) that provides an opinion on whether contract renegotiations above a certain threshold are fair. In addition, The reform also made it mandatory to put to tender any additional works agreed in a renegotiation, and excluded the concessionaire or any related party from the contract.

Table 5: Renegotiations in Chile: Before and after the 2010 Reform

\begin{tabular}{ccccc}
\hline & $\begin{array}{c}\text { Highways } \\
\text { Renegotiation }\end{array}$ & $\begin{array}{c}\text { Transport } \\
\text { Renegotiation }\end{array}$ \\
& No. & (fraction of investment) & No. & (fraction of investment) \\
\hline Before 2010 reform & 29 & $26.1 \%$ & 44 & $27.6 \%$ \\
After 2010 reform & 15 & $0.7 \%$ & 25 & $0.9 \%$ \\
\hline
\end{tabular}

Table 5 shows renegotiations, as a fraction of initial investment, for Chilean PPPs, both before and after the reform of the PPP law of 2010. Since the time elapsed since the reform is relatively short, we only consider renegotiations during construction, both for highway PPPs and for all PPPs in the transport sector. The table shows that renegotiations during construction decreased by more than 90 percent following the reform.

\section{PVR contracts}

The standard user fee PPP is a fixed term contract that is awarded to the firm that bids the lowest fee, shortest term or lowest subsidy. At the end of the fixed term, the infrastructure reverts to the State, which can award a new concession or provide the service either for free or charging user fees.

A fixed-term contract allocates most of the demand risk to the concessionaire. This makes sense when 
the infrastructure is a container terminal, where demand responds to the service standards that are difficult to specify and monitor. But demand forecasts for roads are unreliable and depend mostly on exogenous factors such as macroeconomic activity, and quality of service for a highway is easy to specify and enforce. Thus, in a fixed-term contract the winning bid internalizes exogenous risk by asking for a higher return, i.e., a user fee that generates enough expected income to compensate for demand risk. At the same time, in order to make projects bankable, governments are forced to pledge revenue guarantees. Also, as discussed in the previous section, fixed-term contracts tend to be renegotiated in times of severe economic stress. In brief, the deficient risk allocation of fixed term contracts is expensive.

In this section we argue that exogenous demand risk and opportunistic renegotiations can be mitigated in PPPs with contractible quality of service and high, exogenous, demand uncertainty if present value-ofrevenue (PVR) contract are used (see Engel et al., 1996, 2001). Moreover, the state of the asset (i.e. the project) at the end of the concession must be observable, or the concession becomes in fact a privatization, as no other bidder can compete with an incumbent which is informed. ${ }^{32}$ This applies for highways, airports and other types of infrastructure where demand is large and exogenous and service quality easy to contract upon. Under a PVR contract, the regulator sets the discount rate and tariff schedule, and firms bid the present value of tariff revenue they require to finance, build, operate and maintain the infrastructure. ${ }^{33}$ The firm that makes the lowest bid gets the concession, which ends when the present value of user fees collected equals the winning bid. It follows that the term of the concession automatically adjusts to demand shocks, resulting in a substantial reduction of demand risk borne by the concessionaire. Since tariffs are the main revenue source for the PPP, the contract attains the efficiency gains associated with PPPs discussed in section 4 .

\subsection{Advantages of PVR contracts}

There are several advantages to the PVR contract. First there is a reduction in risk, because demand fluctuations and its associated revenue variations are reflected in a larger or shorter contract term. Since revenue is in present value terms, duration does not matter from the point of view of the profitability of the PPP. ${ }^{34}$ In turn, as pointed out by Tirole (1997), this means that bids are cost based, creating incentives to reduce costs, with reduced or no demand risk, which is appropriate since the firm cannot act upon this risk. This is an efficient assignment of risks, lowering the overall cost of the project. In an estimation of the demand risk in highways that appears in Engel et al. (2001), the reduction in risk associated to a PVR

\footnotetext{
${ }^{32}$ This is the case for water companies, where the state of the underground network is uncertain, and explains why we believe that this paper's conceptual framework for PPPs is not relevant for water concessions. For example, in France, where municipal water concessions have been the norm, there seems to have been few change of a private concessionaire in the many decades in which the system has operated. In 1998, 5 years after the Loi Sapin of 1993 which increased competition for concessions in the sector, $92 \%$ of 582 contracts were renewed while in 1999 the fraction had decreased, and only $85 \%$ concessions were renewed (Cour de Comptes (2003): "La gestion des services publics d'eau et d'assainissement”, Decembre).

${ }^{33}$ User fees considered in the firms' bid are tolls in the case of highways. In the case of airports, they only consider aeronautical revenues (passenger and airport fees); see Engel et al. (2018a) for details.

${ }^{34}$ Given that damage to the road is driven by usage (specially by heavy vehicles), maintenance cost is also related to demand. Hence a longer term is not reflected in higher maintenance costs. The contract does create operation cost risk, but this is a small fraction of total costs.
} 
contract compared to a fixed term contract meant a 30 percent reduction in the cost of a highway. ${ }^{35}$

Cost reduction is not the only benefit from reducing demand risk borne by the firm in a PVR contract. Another advantage is that there is no need for traffic demand guarantees to make the project bankable (i.e., so that banks can led to the project). Usually projects require 20-30 percent equity, so the PPP must obtain construction financing for the remainder, and this is difficult to obtain without a government guarantee of user fee revenues corresponding to 70 percent of the expected value of user fee revenues. PVR contracts do not require these guarantees, which can be costly to the State in case of a severe crisis, which is when they are called.

In addition to their advantages in risk allocation, PVR contracts correct an important deficiency of fixed-term PPPs. In general, PPP contracts are designed to be inflexible, to limit the risk of creeping expropriation by the government. For this reason, fixed term PPP contracts have a hard time incorporating early termination clauses in a way that avoids opportunistic behavior by the government. The reason is that the fair compensation is equal to the revenues that would have accrued, had the concession continued to its end. Because future demand is random, that quantity cannot be calculated with verifiable information with which both parties agree. In contrast, in the case of PVR, the government has the option to unilaterally buy back the concession by paying a "fair" price for the contract. This fair price is equal to the difference between the bid and the present value of toll revenue already collected (with a sum subtracted for savings in maintenance and operational costs). Because the concessionaire's winning bid determines the total amount of present value revenues it requests, the PVR contract is much closer to a complete contract than a fixed-term contract and a fair value for the early buy back option can be calculated at any moment with verifiable accounting information.

Similarly, a PVR contract allows some flexibility in setting user fees. This can be very valuable, for instance to adjust user fees for a metro underground service to better manage the entire public transportation network in a city or in adjusting congestion tolls for an urban highway PPP. In contrast, having flexibility to change user fees in a fixed term PPP comes at the cost of a large increase in revenue risk for the concessionaire. This is not the case under a PVR contract, as long as changes in user fees do not threaten the possibility of obtaining the winning bid revenue.

\section{PVR AND THE TWO MAJOR HIGHWAY PPPS IN THE US DURING THE $1990 \mathrm{~s}^{36,37}$}

The Dulles greenway and the Orange County SR91 are the two main highway PPPs built in the US during the 1990s (see Engel et al., 2011). They both ran into trouble of different sorts, which would have been avoided under PVR.

\footnotetext{
${ }^{35}$ Availability contracts also shield the concessionaire from demand risk because under them the government pays for both capital and operation costs, and they are useful when user fees cannot be charged. In the case of transport infrastructure, however, user fees can fully or partially fund projects, thus avoiding the bureaucratic costs wrought by the government funding machinery. Also, when users are charged, inter modal decisions are efficient and congestion can be managed. Last, when a project is funded with toll revenue, white elephants-i.e., projects whose construction is a net cost to society-are less likely

${ }^{36}$ Based on Gifford et al. (2014) and Engel et al. (2014).

${ }^{37}$ The SR91 project is also analyzed, from a financial valuation perspective, in Lucas en Montesinos (2019).
} 


\section{Dulles Greenway}

The Dulles Greenway is a 14 mile road joining Dulles International Airport with Leesburg, Virginia. Investors put \$40 million in cash and secured \$310 million in privately placed, taxable debt. Loans were to be repaid with toll revenues. Tendered as a fixed term, 42.5 year concession, it was inaugurated in 1995. Demand turned out to be much lower than expected, with actual traffic equal to only one-fourth of projections. When the PPP defaulted in 1996, lenders restructured its debt and investors wrote off part of their equity. In addition, in 2001 the contract term was extended by 20 years, to 2056 .

Despite a major forecast demand error, it was clear that even in low demand scenarios the Dulles Greenway would eventually collect enough tolls to pay for capital and operational expenditures. Therefore, had the PPP been tendered using PVR, the contract term would have extended automatically when demand turned out to be lower than expected, thereby avoiding losses for investors and bondholders. The contract renegotiation and debt restructuring that followed, essentially turned the original fixed term contract into a PVR contract, yet this happened at a high cost.

\section{Orange County's SR 91}

In 1995, the California Department of Transportation (Caltrans) awarded a 35-year concession for a 10-mile segment of the four-lane Riverside Freeway (also called State Route 91) between the Orange-Riverside county line and the Costa Mesa Freeway (State Route 55) to a private firm, California Private Transportation Corporation (CPTC). Motorists used the express lanes to avoid congestion in the non-tolled lanes, paying up to almost $\$ 11$ for a round trip.

By the late 1990s, 33,000 daily trips brought the express lanes to the brink of congestion at peak time, turning the concession into a financial success. At the same time and for the same reasons, users in the non-tolled public lanes were suffering congestion, and an expansion was urgently needed. Nevertheless, the contract included a non-compete clause that prevented Caltrans from increasing capacity at Riverside Freeway without CPTC's consent. Caltrans tried to elude the clause, arguing that expansions were necessary to prevent accidents, but CPTC filed a lawsuit. The verdict stated that non-compete clauses were meant to ensure the financial viability of CPTC and that they restrict Caltrans's right to adversely affect the project's traffic or revenues. Consequently, no new lanes could be built.

Protracted negotiations ensued, and eventually the Orange County Transportation Authority (OCTA) was empowered to negotiate the purchase of the tolled lanes. The value of the concession was controversial since it should have been the present value of profits from the State Route 91 Express Lanes had the franchise continued as originally planned. Although the lanes cost $\$ 130$ million to build, initially the concession's value was set at $\$ 274$ million 
in a controversial (and ultimately unsuccessful) buyout attempt by a non-profit associated with Orange County. After several years of negotiations, with frustrated commuters stuck in traffic in the meantime, the express lanes were bought in January 2003 by OCTA for $\$ 207.5$ million. Press reports suggest that CPTC received additional compensation.

Because this was a fixed-term PPP, demand risk was borne by the concessionaire. Therefore, this dispute was about the value of lost revenues and was unrelated to the cost of the infrastructure. Moreover, because the term was fixed, the value of lost revenues was inherently subjective. Not surprisingly, the concessionaire and OCTA disagreed. The disagreement had real economic cost: it delayed capacity expansion and prolonged costly congestion In contrast, had this been a PVR contract that included a clause allowing government to buy back the concession at any point in time, paying the difference between the winning bid and the amount collected (with a subtraction for savings in maintenance costs), no protracted renegotiation process would have been necessary.

\subsection{PVR in practice}

\section{United Kingdom ${ }^{38}$}

The first present-value-of-revenue PPP contract that we know of was awarded to Trafalgar House on September 29, 1986, to build the Queen Elizabeth II Bridge, conditional on approval from Parlament. The proposal by Trafalgar was deemed the best among eight proposals for crossing the Thames River at Dartford. Among the proposals were five bridges and three tunnels.

The contract stipulated that Trafalgar would buy the two existing tunnels for $£ 43$ million, build a new 450 meter long bridge and operate all three for a maximum of 20 years or until toll fees paid off the debt and equity, whichever happened first. The project had four shareholders: Trafalgar House (50\%), Kleinwort Benson (16.5\%), Prudential (16.5\%) and Bank of America (17\%). The consortium financed the bridge with subordinated debt issued by insurance companies, and term loans by banks. Project finance was used and the concessionaire had only nominal equity. Interest on the syndicated loan were floating, at a margin of between 0.75 and $1.25 \%$ above prime.

The bridge opened in 1991 and after accruing the necessary toll revenue, the contract terminated in March of 2002, almost ten years before the maximum concession term of 20 years. The SPV in charge of the PPP was liquidated, the bridge reverted to public management and the government began collecting tolls, now referred to as charges.

The Second Severn Crossing PPP on the Severn Estuary, which was tendered in 1990 and opened in 1996, also used a PVR contract. The contract stipulated a term of 30 years or until the concessionaire collected $£ 995.8$ million (in July 1989 prices), whichever occurred first. As with the Queen Elizabeth II bridge, the PPP was financed fully with debt. Control of the crossing and the

\footnotetext{
${ }^{38}$ Based on Engel et al. (2014) and Levy (1996).
} 
original Severn Bridge reverted to the UK government on 8 January 2018, after the required revenue had been collected. At that point responsibility for operating the bridge passed to Highways England, a public entity.

\section{Chile $^{39}$}

Figure 6 shows the cumulative investment in transport PPPs in Chile since the PPP program was launched in 1993 with the El Melón tunnel. As can be seen in the figure, initially all PPPs were fixed term. The first PVR contract was auctioned in 1998, but after 2006 PVR contracts became the norm. Note that a third type of contract -the so-called revenue distribution mechanism or MDI- appeared in 2002. These were five fixed-term PPPs that were renegotiated and turned into variable-term contracts in 2002, after their revenue plummeted during a recession in the late 1990s. By 2017, 29 of the 66 PPPs awarded were variable-term contracts. As Figure 2 shows, by 2017 the cumulative investment in transport PPPs in Chile exceeded USD 12 billion. 55 percent of all investment had been made with (or turned into) variable-term contracts.

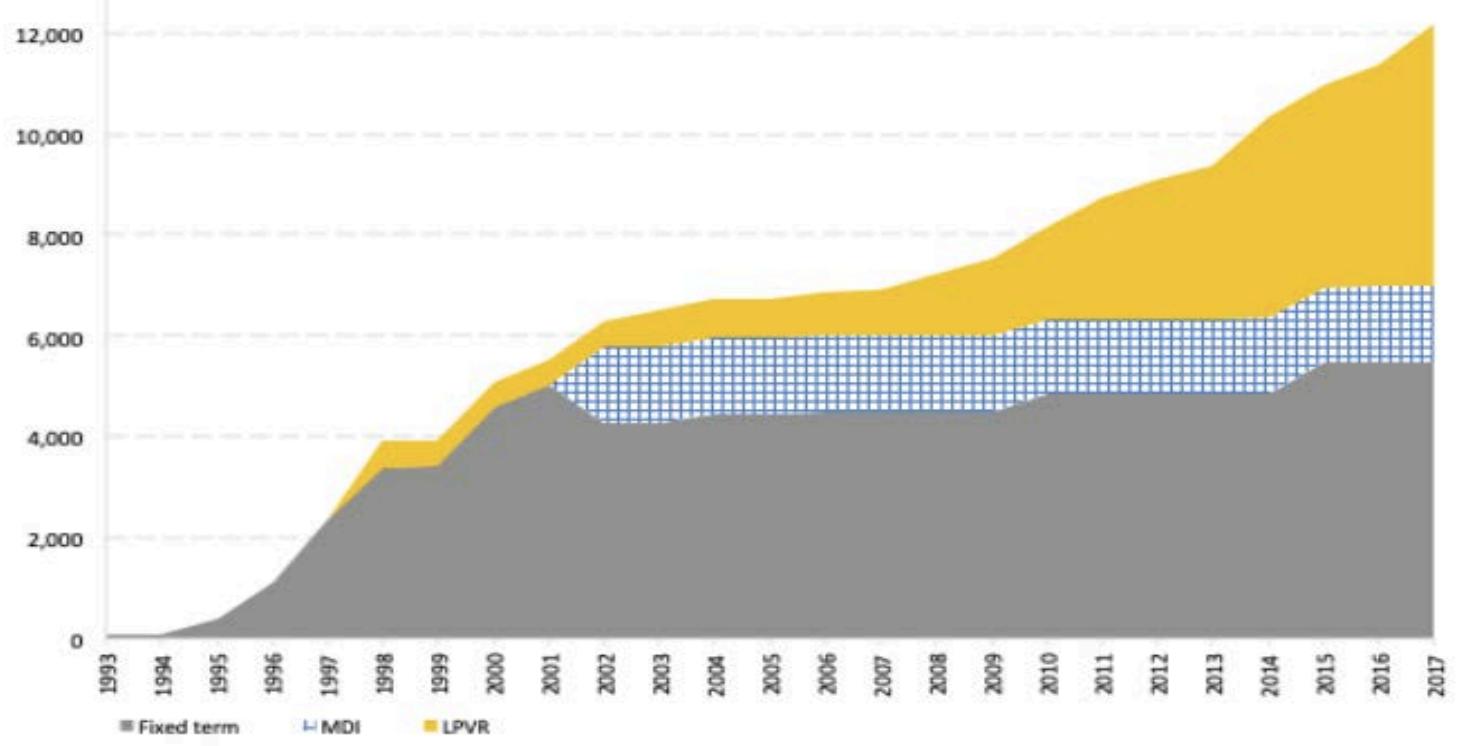

Figure 6: Value of PVR Contracts in Chile. Source: Authors

\subsection{Financing and renegotiations: theory and evidence}

Flexible term contracts have been used in the UK, Chile, Colombia and Portugal. Given all the advantages described above, begs the question of why they have not been used more broadly.

\footnotetext{
${ }^{39}$ Based on Engel et al. (2019c)
} 
We can think of two reasons. First, there exists a belief that PVR financing is more difficult (see Klein, 1997, for an early example). ${ }^{40}$ We argue below that this belief is incorrect. Second, PVR makes it harder to renegotiate PPP contracts, which may explain why they have been opposed by concessionaires. ${ }^{41}$

We explain next why financing of a PVR contract compares well with financing of fixed- term contracts. We also explain why PVR contracts make opportunistic renegotiations less likely and present evidence consistent with this explanation.

One reason why structuring PVR contracts may be harder is that the contract term is not known in advance. This would seem to impose additional challenges on fixed maturity debt which may make financing more costly. Another concern is that the risk of debt prepayment by bondholders will be higher under PVR contracts, since the SPV will want to pay its debt and dissolve early when demand turns out to be high.

To address the above concerns, we begin by noting that demand realizations are independent of the type of contract being used. Therefore, if tolls are the same, the per period cash flows generated by a project depend only on demand realizations, and not on the type of PPP contract. It follows that the main difference between a fixed term and a PVR contract is that the latter lasts longer in low demand scenarios, and ends earlier in high demand scenarios. Therefore, when demand turns out to be low, the concessionaire can automatically tap revenues which are unavailable under a fixed term contract to repay debt. This implies that the risk borne by debt financiers will be lower under PVR, and that the PPP can take a higher leverage.

At the same time, the fact that the contract ends sooner in high demand scenarios implies a higher prepayment risk under PVR. However, the prepayment option does not come at a significant cost to lenders, because it is not triggered by a strategic response of the borrower to the fall in interest rates. On the contrary, prepayment is triggered by an exogenous event -an unexpectedly high demand for the project-. Moreover, because exogenous prepayments occur when demand for the project is high, they are likely to happen when the economy is booming and interest rates are high. By contrast prepayment risk is usually costly for lenders because borrowers strategically make a prepayment when interest rates fall and they can refinance at lower cost. The fact that PVR is not correlated to these scenarios means prepayment risk is low or even inexistent. The Chilean experience with financing PVR contracts is consistent with the above arguments (see Engel et al., 2019c).

Summing up, PVR contracts may be viewed as having a built-in renegotiation clause that is triggered by low demand realizations. When demand is lower than expected, the contract length extends automatically and total revenues for the firm, in present value, are unaffected. In contrast with fixed term PPPs, no costly contract renegotiation is needed.

Table 6 compares renegotiations under fixed-term and PVR, for highway PPPs in Chile (similar

\footnotetext{
${ }^{40}$ For financing of PPPs in general, and the important role of project finance, see, for example, Ehlers, Packer and Remolona (2014), Inderst (2010, 2013)

${ }^{41}$ The PPP sector lobbied against PVR when it became the standard contract for highway and airport PPPs in Chile in 2007.
} 
results are obtained if airport PPPs are included as well). The table reports renegotiations, as a fraction of the initial investment, both during construction and during the first eight years of operation. $^{42}$

Table 6: Renegotiations in Chile: Fixed-term vs. PVR

\begin{tabular}{ccccc}
\hline Period considered & No. $\begin{array}{c}\text { Fixed term } \\
\text { Renegotiation } \\
\text { (average) }\end{array}$ & No. & $\begin{array}{c}\text { PVR } \\
\text { Renegotiation } \\
\text { (average) }\end{array}$ \\
\hline Construction: & 20 & $32.0 \%$ & 15 & $3.6 \%$ \\
First 8 years of operation: & 20 & $25.2 \%$ & 15 & $2.5 \%$ \\
\hline Total (construction + first 8 years of operation): & 20 & $57.2 \%$ & 15 & $6.1 \%$ \\
\hline
\end{tabular}

Clearly, renegotiations under PVR have been considerably lower - about one tenth - than under the fixed-term contracts. This is consistent with PVR contracts providing less incentives for concessionaires to renegotiate contracts, since low demand realizations have very little impact on their bottom line.

\section{Conclusion}

One of the main conclusions of this chapter is that PPPs can be a useful instrument of public policy, even though the main motivation for their use is based on a misconception. The erroneous claim that PPPs free up public funds is popular among policymakers, because they can increase infrastructure spending and circumvent budgetary controls while not increasing the deficit. However, the reason why PPPs can make an important contribution to social welfare is that they can deliver efficiency gains. We described eight potential sources of improvements in productivity under PPPs, prominent among them is cheaper and better maintenance.

It is often argued that PPPs should be preferred over public provision only when the efficiency gains under PPPs are large enough to compensate the higher cost of private debt. ${ }^{43}$ We believe this argument is weak, as it ignores the origin of the lower interest paid on public debt: in times of economic stress, governments can resort to options that are not available to private firms, such as increasing taxes or lowering social expenditure to continue paying its financial obligations (Klein, 1997). These options entail a social cost that is not reflected in the lower rate of interest paid by public debt. Furthermore, using the government cost of funds as the discount rate, contradicts

\footnotetext{
${ }^{42}$ Considering longer periods of operation reduces significantly the number of projects with PVR, since these contracts began being used on a regular basis only in 2007.

${ }^{43}$ For example, the January 2019 NAO Report "PFI and PF2" states that "the higher cost of finance, combined with these other costs, means that overall cash spending on PFI and PF2 projects is higher than publicly financed alternatives." And "Our analysis of these data for one group of schools shows that PF2 costs are around forty per cent higher than the costs of a project financed by government borrowing", from page 19 of the Report.
} 
the fair value approach which "posits that the cost of capital for any real or financial investment reflects the market price of the associated risks" (Lucas and Montesinos, 2019).

Another reason why interest rates paid on private debt to finance infrastructure under a PPP are higher than rates under public provision is poor contract design. This is the case, for example, when the concessionaire is forced to bear demand risk beyond its control, as is the case for fixed term PPP contracts.

Experience thus far suggests that successful PPPs require careful project and contract design by the government and good governance, both during the procurement and operation stages. However, there is a widespread belief that using PPPs the government can delegate project design and delivery, and transfer all relevant risks to the concessionaire through the PPP contract. The outcome of poor contract design and deficient governance are pervasive renegotiations even in the initial stages of the PPP contract. Renegotiations generate problems, because they substitute bilateral renegotiations for competitive tendering, and thus stimulate lowballing at the tendering stage. Pervasive renegotiations can also be used by political incumbents to bring forward infrastructure spending. They also create adverse selection by attracting firms with a comparative advantage at renegotiating over technical skills, and generate moral hazard by allowing governments and concessionaires to renegotiate away their mistakes in the design of the project. In addition, recent corruption scandals suggest a link between renegotiations and bribing. And because renegotiations tend to delay project completion, they foster cost overruns through accumulation of overheads. This is not to say that all contract renegotiations reduce public welfare, but when renegotiations occur in the first years of the contract, there is a strong presumption that this is the case.

On the other hand, when SPV equity holders and creditors know that they face a hard budget constraint and the possibility of losses if the project is not well designed, built, maintained and operated, incentives are aligned and it becomes likely that PPPs realize the efficiency gains they promise. In the last 30 years of studying PPPs we have compiled a set of best practices.

First, PPPs would become more credible if their link to the intertemporal fiscal constraint is acknowledged. This occurs if investment in PPPs is included in public accounts the same way as public investment, since they impact the intertemporal fiscal constraint similarly. Second, careful planning, project design, and project management help ensure that PPPs fulfill their promise. Careful planning reduces the frequency of costly mistakes and of events that require modifications to the contract, and thus the need for renegotiations. In addition, if renegotiations are reviewed and possibly approved by an independent expert panel, the incentives to renegotiate contracts are reduced. Similarly, if any additional works required by the project once it has been awarded is tendered competitively, there are fewer incentives to attempt to change the conditions of the project by these additions. Finally, if concessionaires are not required to bear demand risk which they cannot control, the cost of the project is lower.

In 2010 Chile modified its PPP law, introducing an independent panel to review contract rene- 
gotiations and excluded concessionaires from building additions agreed in renegotiations. In addition, since 2007 Chile has routinely used PVR contracts, a flexible term contract that shields the concessionaire from demand risk it cannot control. While we cannot prove causality, these reforms were based on sound economic analysis and were followed by a substantial decrease in renegotiations of more than 90 percent. Which illustrates the more general point we make in this paper, namely that governance and careful contract design are important to reap the benefits from PPPs. 


\section{References}

[1] Akinbode, A. and P. Vickers (2017). "Dispute Management: Peace in our pipeline." Procurement \& Outsourcing fournal, March.

[2] Airoldi, M., J. Chua, P. Gerbert, J. Justus and R. Rilo (2013), Bridging the Gap: Meeting the Infrastructure Challenge with Public-Private Partnerships. Boston: The Boston Consulting Group.

[3] Blanc-Brude, F. and B. Ismail (2013). "Who is Afraid of Construction Risk?" Working Paper EDHEC-Risk Institute.

[4] Blanchard, O.J. and F. Giavazzi (2004). "Improving the Sgp Through a Proper Accounting of Public Investment," CEPR Discussion Paper No. 4220

[5] Campos, N., E. Engel, R. Fischer and A. Galetovic (2019). "Renegotiations and Corruption in Infrastructure: The Odebrecht Case." SSRN Working Paper.

[6] Dealogic (2012). Project Finance Review. Full year 2012.

[7] Donaghue, B. (2002) . "Statistical Treatment of Build-Operate-and-Transfer Schemes." Working Paper Nr. 02/167. Washington, DC: International Monetary Fund.

[8] Ehlers, T., F. Packer and E. Remolona (2014). "Infrastructure and Corporate Bond Markets in Asia," in Heath, A. and M. Read (eds.) Financial Flows and Infrastructure Financing. Sydney: Reserve Bank of Australia.

[9] Engel, E., Fischer R., and Galetovic A. (1996). "Highway auctions in Chile." in Spanish, Estudios Públicos, 61, 6-37..

[10] Engel, E., Fischer R., and Galetovic A. (2001). "Least-Present-Value-of Revenue Auctions and Highway Franchising," Journal of Political Economy, 109 (5), 993-1020.

[11] Engel, E., Fischer R., and Galetovic A. (2011). "Public-Private Partnerships to Revamp U.S. Infrastructure." Discussion paper 2011-02. Washington, DC: The Hamilton Project - Brookings Institution.

[12] Engel, E., Fischer R., and Galetovic A. (2013). "The Basic Public Finance of Public Private Partnerships.” fournal of the European Economic Association 11 (1), 83-111.

[13] Engel, E., Fischer R., and Galetovic A. (2014a), The Economics of Public-Private Partnerships: A Basic Guide. Cambridge University Press.

[14] Engel, E., Fischer R., and Galetovic A. (2014b), "Finance and Public-Private Partnerships: A Roadmap." Background paper for the Global Financial Development Report of the World Bank.

[15] Engel, E., Fischer R., and Galetovic A. (2018a). "The joy of flying: Efficient airpot PPP contracts," Transport Research Part B, 114 131-146.

[16] Engel, E., R. Fischer R., and A. Galetovic (2019a). "Soft budgets and renegotiations in transport PPPs: An equilibrium analysis," Economics of Transportation, 17, 40-50.

[17] Engel, E., Fischer R., and Galetovic A. (2019b). "Renegotiations and adverse selection in a model with endogenous firm formation," Work in progress.

[18] Engel, E., R. Fischer, A. Galetovic and G. de Rus (2018b). "Public-Private Partnerships in Infrastructure: Reforming the Spanish Toll Road Concessions System," (in Spanish) Cuadernos de Extensión furídica, 31, 2018.

[19] Engel, E., R. Fischer, A. Galetovic and M. Hermosilla (2009). 'Renegotiation of concessions in Chile," Estudios Públicos, 151-205, Summer 2009. 
[20] Engel, E., R. Fischer, A. Galetovic and J. Soto (2019c). "Financing PPP Projects with PVR Contracts: Theory and Evidence from the UK and Chile." Presented at the Finance of Infrastructure Symposium, Hoover institution, Stanford University, May 2019.

[21] Esguerra, J. (2003). “The Corporate Muddle of Manila’s Water Concessions”, WaterAid and Tearfund.

[22] Eurostat (2016). Manual on Government Deficit and Debt. Eurostat, Brussels.

[23] Flyvbjerg, B., N. Bruzelius and W. Rothengatter (2003). Megaprojects and risk: An anatomy of ambition. Cambridge: Cambridge University Press.

[24] Gifford, J., Bolañs, L., and Daito, N., (2014). "Renegotiation of Transportation Public-Private Partnerships: The US Experience," Discussion Paper No 2014-16, International Transport Forum. Paris, OECD.

[25] Gómez-Ibáñez, J.A. and J. Meyer (1993). Going Private: The International Experience with Transport Privatization. Washington, DC: Brookings Institution.

[26] Grimsey, D. and M.K. Lewis (2002). "Evaluating the Risks for Public-Private Partnerships for Infrastructure Projects." International Journal of Project Management, 20, 107-118.

[27] Grimsey, D. and M.K. Lewis (2004). The Economics of Public-Private Partnerships. Northampton: Edward Elgar.

[28] Grout, P. and M. Stevens, "The Assessment: Financing and Managing Public Services," Oxford Review of Economic Policy 19, 215-234, 2003.

[29] Guasch, J.L. (2004). Granting and renegotiating infrastructure concessions: doing it right. The World Bank.

[30] Guasch, J.L., J.J. Laffont and S. Straub (2007). "Concessions of infrastructure in Latin America: government-led renegotiations.". J. of Applied Economics 22, $1267 ? 1294$.

[31] Guasch, J.L., Laffont, J.J., and Straub, S. (2008). "Renegotiation of concession contracts in Latin America: Evidence from the water and transport sectors." International fournal of Industrial Organization, 26(2), 421-42.

[32] Hall, G. (1998). “Private Opportunity, Public Benefit?” Fiscal Studies 1940.

[33] Hart, O. (2003). "Incomplete Contracts and Public Ownership: Remarks and an Application to Public-Private Partnerships," Economic Journal, 113, C69-C76.

[34] Heald, D. (1997). "Privately Financed Capital in Public Services.” The Manchester School, 65, 568-598.

[35] Heald, D. (2010). “The Accounting Treatment of of Public Finance Initiative Projects.” In The Budget Report.

[36] Heald, D. and G. Georgiou (2009). "The Substance of Accounting for Public-Private Partnerships." Financial Accountability \& Management, 27, 217-247. London: House of Commons.

[37] Inderst, G. (2010). "Infrastructure as an Asset Class," EIB Papers, 15, 70-104.

[38] Inderst, G. (2013). “Private Infrastructure Finance and Investment in Europe,” EIB Working Papers 02.

[39] Irwin, T. (2007). Government Guarantees: Allocating and Valuing Risk in Privately Financed Infrastructure Projects. Washington, DC: The World Bank.

[40] Klein, M. (1997). "Comments on the proposal by Engel, Fisher y Galetovic on highway auctions”, in Spanish, Estudios Públicos, 67, 215-223.

[41] Leslie, A. (2019). “Managing Hospital Assets Under PPPs.” Masters thesis, University of Chile.

[42] Levy, S.M. (1996). Build, Operate, Transfer: Paving the way for tomorrow's infrastructure, John Wiley. 
[43] Lucas, D. and J. Montesions (2019). "A Fair Value Approach to Valuing Public Infrastructure Projects and the Risk Transfer in Public Private Partnerships." Prepared for the NBER Conference on Economics of Infrastructure Investment.

[44] Maskin, E. and J. Tirole (2008). "Public-Private Partnerships and Government Spending Limits." International fournal of Industrial Organization, 26, 412-420.

[45] National Audit Office, UK (2018). "PF1 and PF2." Report by the Comptroller and Auditor General. Ordered by the House of Commons to be printed on 17 January 2018.

[46] OECD (2008). Public-Private Partnerships: In Pursuit of Risk Sharing and Value-for-Money. Paris: OECD.

[47] Raisbeck, P., C. Duffield and M. Xu (2010). "Comparative performance of PPPs and traditional procurement in Australia”, Construction Management and Economics 28(4), 345-359.

[48] Rioja, F.K. (2003). "Filling Potholes: Macroeconomic Effects of Maintenance versus New Investments in Public Infrastructure," f. of Public Economics, 87, 2281-2304.

[49] Sarmento, J. and L. Renneboog (2014). "The Portuguese Experience with Public-Private Partnerships”, Tilburg University Discussion Papers 05-2014, January.

[50] Schwartz, G., A. Carbacho and K. Funke (2008). Public Investment and Public-Private Partnerships. Houndmills: Palgrave MacMillan.

[51] Singh, R. (2018). "Dos choice of procurement matter for cost and quality of infrastructure?: Comparison of quality and cost of roads.” IGC Working Paper S-89209-INC-2.

[52] Tirole, J. (1997). "Comments on the proposal by Engel, Fisher y Galetovic on highway auctions," in Spanish, Estudios Públicos, 67, 201-214.

[53] TRIP (2013). "Bumpy Roads Ahead: America?s Roughest Rides and Strategies to Make our Roads Smoother." Washington, DC.

[54] Wu, X. and N. Malaluan (2007). "A Tale of Two Concessionaires: A Natural Experiment of Water Privatisation in Metro Manila”, Urban Studies, 45(1), 207-229.

[55] Yescombe, E.R. (2007). Public-Private Partnerships: Principles of Policy and Finance, Butterworth-Heinemann, London, UK. 